\title{
DANOS CAUSADOS PELA MANCHA ANGULAR EM FEIJOEIRO, NO MUNICIPIO DE PIRACICABA
}

\author{
CLÁUDIA VIEIRA GODOY
}

Engenheiro Agrônomo

Orientadora: Prof ${ }^{a}$. D $x^{a}$. IILIAN AMORIM

Dissertação apresentada à Escola
Superior de Agricultura "Luiz de
Queiroz", da Universidade de são
Paulo, para obtenção do título de
Mestre em Agronomia, Area de
Concentração: Eitopatologia.

PIRACICABA

Estado de São Paulo.- Brasil

Julho - 1995 
Dados internacionais de Catalogação na Publicação (CIP)

Divisão de Biblioteca e Documentação - CAMPUS "LUIZ DE QUEIROZ"/USP

Godoy, Cláudia Vieira

Danos causados pela mancha angular em feijoeiro, no município

de Piracicaba. Piracicaba, 1995.

71p. ilus.

Diss.(Mestre) - ESALQ

Bibliografia.

1. Feijão - Doença 2. Fungo fitopatogènico 3. Mancha angular em feijoeiro 1. Escola Superior de Agricultura Luiz de Queiroz, Piracica ba

CDD $\quad 635.652$

632.32 
DANOS CAUSADOS PELA MANCHA ANGULAR EM FEIJOEIRO, NO MUNICÍPIO DE PIRACICABA

\author{
CLÁUDIA VIEIRA GODOY
}

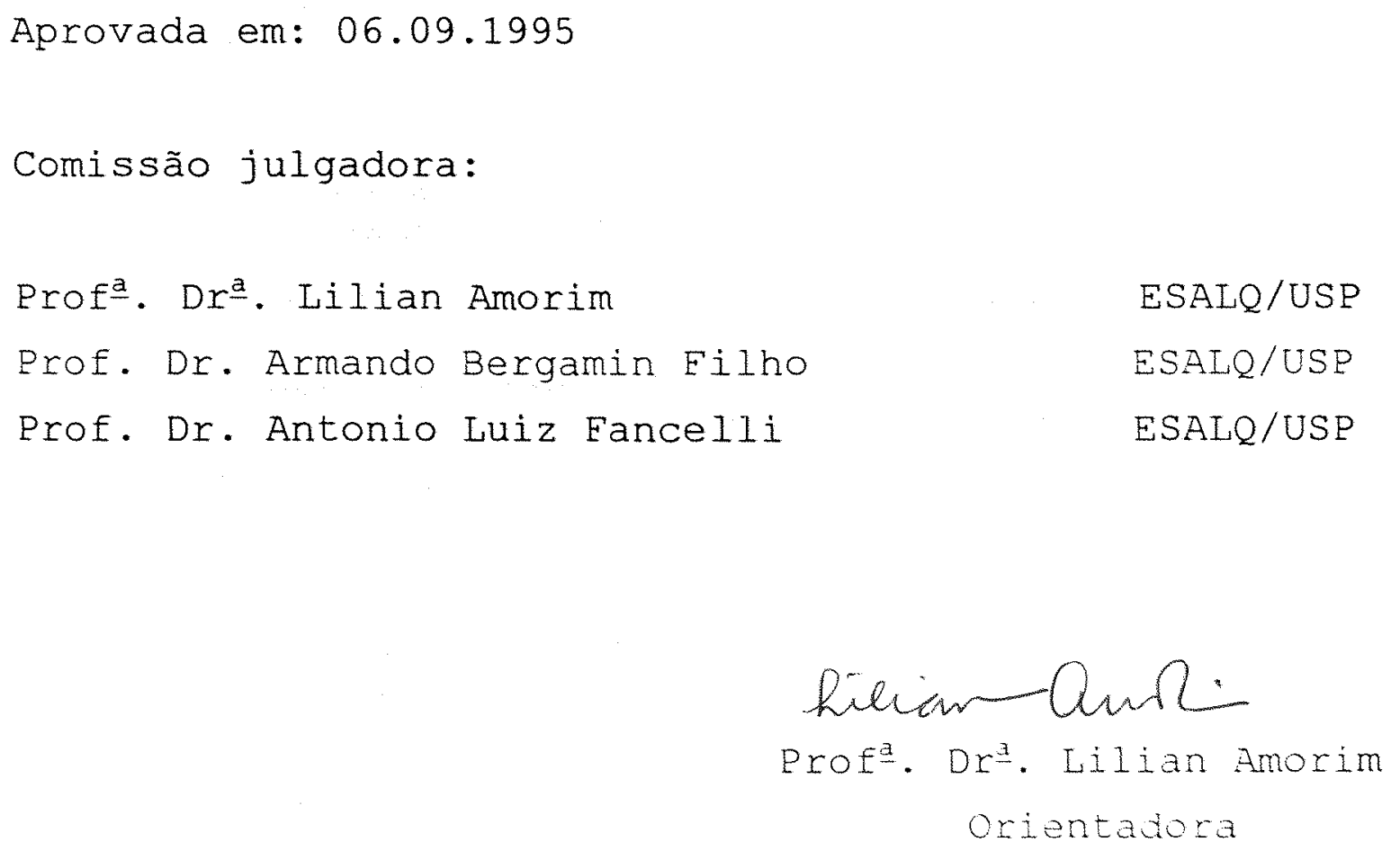


Aos meus pais, Luiz Fexnando $\theta$ Maria Aparecida DEDICO 


\section{AGRADECIMENTOS}

Agradeço a todas as pessoas que direta ou indiretamente contribuíram para a realização deste trabalho, colegas, professores e funcionários do Departamento de Eitopatologia da ESALQ/USP pela atenção e amizade durante todo o curso, em especial:

À Professora Lilian Amorim, pela orientação, apoio e amizade.

Aos Professores Armando Bergamin Eilho, Richard D. Berger e Bernhard Hau pelas idéias e auxílio na análise dos dados.

Ao Renato B. Bassanezi e à Marise C. Martins pelo auxílio nas avaliações e amizade constante.

Ao Sr. Pedro da Silva pelo auxilio na instalação dos ensaios de campo.

Aos colegas epidemiologistas: Marilene, Maristella, Gisele e Marcelo pela convivência e amizade.

À Coordenação de Aperfeiçoamento de pessoal de Nível Superior (CAPES) pelo auxílio financeiro. 


\section{SUMÁRIO}

Página

LISTA DE FIGURAS

vii

$x i$

LISTA DE APÊNDICES.

xii

RESUMO

$x i v$

SUMMARY

$x \vee i$

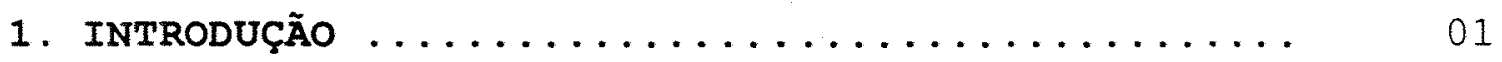

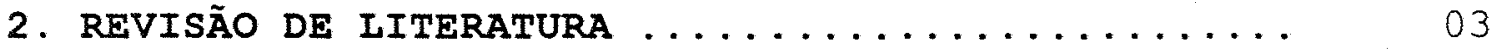

2.1. A mancha angular do feijoeiro ...........

2.1.1. Agente causal e ciclo de relações patógeno - hospedeiro .......... 03

2.1.2. Controle da doença ............ 05

2.2. Avaliação de danos devido a doenças ...... 07

2.2.1. Terminologia empregada ......... 07

2.2.2. Delineamentos experimentais para avaliação de danos ............. 08

2.2.3. Modelos tradicionais de avaliação de danos .................... 11

2.2.4. Avaliação de danos através da área foliar fotossintetizante .........

3. MATERIAI E MÉTODOS .................. 16

4. RESULtados E DISCUSSÃo ................ 24

4.1. Avaliação de danos causados pela mancha

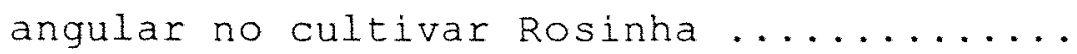

4.2. Avaliação de danos causados pela mancha

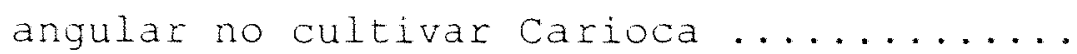

4.3. Manejo da mancha angular do feijoeiro baseado na área foliar sadia das plantas.

5. CONCLUSŌES . 
APÊNDICES ........................ 


\section{IISTA DE FIGURAS}

FIGURA $\mathrm{N}^{\circ}$

Página

01 Inoculações cruzadas realizadas no ensaio de campo para o cultivar Carioca.

02 Inoculações cruzadas realizadas no ensaio de campo para o cultivar Rosinha.

03 Escala diagramática de severidade (porcentagem de área foliar afetada) da man cha angular do feijoeiro ...........

04 Distribuição da severidade (em AUDPC) obtida nas plantas do cultivar Rosinha marcadas no campo ..............

05 Relação entre área foliar do feijoeiro $\left(\mathrm{cm}^{2}\right)$ e severidade (\%) com a produção (g), em seis avaliações (cultivar Rosinha) $\ldots \ldots \ldots \ldots \ldots \ldots \ldots \ldots \ldots \ldots \ldots \ldots \ldots \ldots$

06 Relação entre área foliar do feijoeiro $\left(\mathrm{cm}^{2}\right)$ e severidade (\%) com o número de vagens por planta, em seis avaliaçōes (cultivar Rosinha) ..............

07 Relação entre as variáveis AUDPC (a), AULAPC (b), HAD (c) e HAA (d), e produção (gramas) para o cultivar Rosinha $\ldots \ldots \ldots \ldots \ldots \ldots \ldots \ldots \ldots \ldots \ldots \ldots \ldots \ldots$

08 Relação entre as variáveis $\operatorname{AUDPC}(a)$, AULAPC (b), HAD (c) e HAA (d), e número 
de vagens por planta para o cultivar Rosinha $\ldots \ldots \ldots \ldots \ldots \ldots \ldots \ldots \ldots$

09 Relação entre HAD com número de vagens por planta (a) e produção em gramas (b) para o cultivar Rosinha $(\bullet$ - média de cinco plantas) $\ldots \ldots \ldots \ldots \ldots \ldots \ldots$

10 Relação entre as variáveis AUDPC (a), AULAPC (b), HAD (c) e HAA (d), e número de sementes por vagem para o cultivar

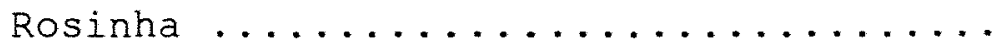

11 Relação entre as variáveis AUDPC (a), AULAPC (b), HAD (c) e HAA (d), e peso de 100 sementes para o cultivar Rosinha

12 Curvas de progresso do índice de área foliar sadia para plantas sadias 10 média de 20 plantas) e doentes $(\bullet-$ média de 20 plantas), e suas respectivas produções médias (cultivar Rosinha) $\ldots \ldots \ldots \ldots \ldots \ldots \ldots \ldots \ldots \ldots \ldots \ldots \ldots$

13 Curvas de progresso do indice área foliar nas parcelas do cultivar Rosinha com diferentes concentrações de inóculo. Cada curva representa a média das seis plantas de cada parcela. As concentraçōes do inóculo crescem no sentido $a, c, b$ e $d \ldots \ldots \ldots \ldots$

14 Distribuição da severidade (em AUDPC) 
obtida nas plantas do cultivar Carioca

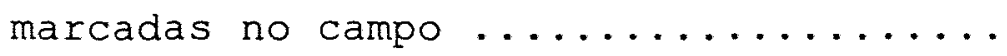

15 Relação entre área foliar do feijoeiro $\left(\mathrm{cm}^{2}\right)$ e severidade (\%) com a produção (g), em cinco avaliações (cultivar Carioca) $\ldots \ldots \ldots \ldots \ldots \ldots \ldots \ldots \ldots$

16 Relação entre área foliar do feijoeiro $\left(\mathrm{cm}^{2}\right)$ e severidade (\%) com o número de vagens por planta, em cinco avaliações (cultivar Carioca) ..............

17 Relação entre as variáveis AUDPC (a), AULAPC (b), HAD (c) e HAA (d), e produção (gramas) para o cultivar Carioca ....................

18 Relação entre as variáveis AUDPC (a), AULAPC (b), HAD (c) e HAA (d), e número de vagens por planta para o cultivar

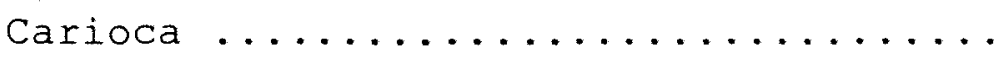

19 Relação entre HAD com número de vagens por planta (a) e produção em gramas (b) para o cultivar Carioca (- - média de cinco plantas $\ldots \ldots \ldots \ldots \ldots \ldots \ldots$

20 Relação entre indice de área foliar sadia e produção(g) para as plantas sadias do cultivar carioca, nas cinco datas de avaliação (- todas plantas, o 
- média de cinco plantas) ........... 52

21 Relação entre índice de área foliar sadia e número de vagens por planta para as plantas sadias do cultivar Carioca, nas cinco datas de avaliação (• - todas plantas, o - média de cinco plantas) $\ldots \ldots \ldots \ldots \ldots \ldots \ldots \ldots$ 


\section{IISTA DE TABELAS}

TABETAA $\mathrm{N}^{\circ}$

Página

01 Concentrações de inóculo aplicadas nas parcelas do cultivar Carioca .........

02 Concentrações de inóculo aplicadas nas parcelas do cultivar Rosinha .........

03 Produções médias das seis plantas marcadas em cada parcela do ensaio com o cultivar Rosinha ................ 
xii

\section{LISTA DE APÊNDICES}

APÊNDICE $\mathbf{N}^{\circ}$

Página

01 Dados de radiação global (cal $/ \mathrm{cm}^{2} \star \mathrm{dia}$ ) para os períodos de avaliação dos ensaios. Datas em negrito correspondem às datas de avaliação .............

02 Relação entre as variáveis AUDPC (a), AULAPC (b), HAD (c) e HAA (d), e número de sementes por vagem para o cultivar

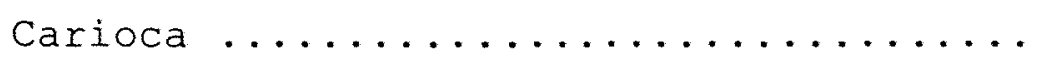

03 Relação entre as variáveis AUDPC (a), AULAPC (b), HAD (c) e HAA (d), e peso de 100 sementes para o cultivar Carioca...

04 Curvas de progresso do indice de área foliar sadia para plantas sadias 10 média de 20 plantas) e doentes $(\bullet-$ média de 20 plantas) (cultivar Carioca)

05 Curvas de progresso do índice de área foliar nas parcelas do cultivar Carioca com diferentes concentrações de inóculo. Cada curva representa a média das seis plantas de cada parcela. As concentrações do inóculo inicial crescem no sentido $a, c, b$ e $d \ldots . . . . .$. marcadas em cada parcela do ensaio com o

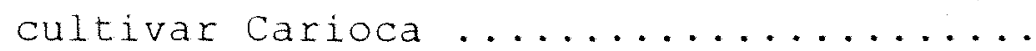


07 Relação entre índice de área foliar sadia e produção (g) para as plantas sadias do cultivar Rosinha, nas seis datas de avaliação (* todas plantas, o - média de cinco plantas) ...........

08 Relação entre índice de área foliar sadia e número de vagens por planta para as plantas sadias do cultivar Rosinha, nas seis datas de avaliação ( - todas plantas, o - média de cinco plantas)... 
xiv

\title{
DANOS CAUSADOS PELA MANCHA ANGULAR EM FEIJOEIRO, NO MUNICÍPIO DE PIRACICABA
}

\author{
Autora: CIÁUDIA VIEIRA GODOY \\ Orientadora: PROF ${ }^{a}$. $D R^{a}$. IILIAN AMORIM
}

RESUMO

Com o objetivo de obter dados para o estabelecimento de uma função de dano para o patossistema feijoeiro mancha angular (Phaeoisariopsis griseola), foram realizados ensaios no campo experimental do Departamento de Fitopatologia da ESALQ/USP, no município de Piracicaba/SP, com os cultivares Carioca comum (1993) e Rosinha G-2 (1994). A metodologia utilizada foi a de plantas individuais (JAMES \& TENG, 1979), onde plantas marcadas no campo foram inoculadas com suspensões de esporos de $P$. griseola em diferentes concentrações. Foram avaliadas a área foliar, a severidade de doença e a produção de cada planta marcada.

Foi verificada a relação das variáveis de produção (número de vagens, peso de grãos, número de sementes por vagem e peso de 100 sementes) com a variável de doença (área sob a curva de progresso da doença - AudPC) proposta por VANDERPIANK (1963), e com as variáveis de área foliar sadia lárea sob a curva de progresso da área foliar AulAPC, duraça da área foliar sadia - HAD e absorça da área foliar sadia - HAA) descritas por WAGGONER \& BERGER (1987).

Para os dois ensaios, năo Eol encontrada correlaço entre severidade de doença (AUDPC) e as variáveis de 
produção. No entanto, encontrou-se correlação entre área foliar sadia e os componentes da produção número de vagens e peso de grãos. Essas correlações, determinadas através de regressões lineares, foram maiores para o cultivar Carioca, que apresentou uma menor severidade de doença, quando comparado com o cultivar Rosinha. Os componentes da produção peso de 100 sementes e número de sementes por vagem não apresentaram correlação com nenhuma das variáveis.

Não foi possivel estabelecer uma função de dano baseada na severidade da doença, tradicionalmente utilizada em outros patossistemas. A substituição de severidade de doença, por área foliar sadia, permitiu uma quantificação mais acurada da produção. Este trabalho fornece dados para um futuro estudo de implementação de um sistema de manejo integrado desta doença, baseada nas variáveis de área foliar sadia, seguindo a proposta de LOPES et alii (1994) e BERGAMIN FILHO et alii (1995). 
LOSSES DUE TO ANGULAR LEAE SPOT OF BEAN, IN PIRACICABA

\section{Author: CLÁUDIA VIEIRA GODOY}

Adviser: PROF. DR. IILIAN AMORIM

\section{SUMMARY}

To generate reliable data to establish a damage function in the pathosystem bean - angular leaf spot (Phaeoisariopsis griseola), field trials were carried out in experimental fields at the Department of plant Pathology, in Piracicaba, with cultivars Carioca comum (1993) and Rosinha G-2 (1994). The methodology applied was the use of individual plants (JAMES \& TENG, 1979), where marked plants were inoculated with spore suspensions of $P$. griseola at different concetration. Assessements were made on leaf area, disease severity and yield.

It was verified the relation between the assessed yield variables (number of pods, seed weight, number of seeds per pod and weight of 100 seeds) and the variable of disease (area under disease progress curve - AUDPC), proposed by VANDERPLANK (1963), and between the variables of healthy leaf area larea under the leaf area progress curve - AULAPC, healthy leaf area duration - HAD, and healthy leaf area absorption - HAA), described by WAGGONER \& BERGER (1987).

For the two trials, a correlation between disease severity (AUDPC) and the variables of yield could not be found. However, correlation was established between healthy leaf area and yield components (number of pods and seed weight). These correlations, as indicated by linear 
regression, were better in the cultivar Carioca, with less disease severity, than with cultivar Rosinha. The yield components: weight of 100 seeds and number of seeds per pod, were not correlated with any of the variables.

It was not possible to establish a damage function based on disease severity, traditionally used in other pathosystems. The substitution of disease severity, by healthy leaf area, allowed a better quantification of yield. This work provides data for a future study for the implementation of an integrated disease management system, using the variable healthy leaf area, as proposed by LOPES et alii (1994) and BERGAMIN FILHO et alii (1995). 


\title{
1. INTRODUÇÃO
}

\begin{abstract}
Embora seja componente da cesta básica, a participação do feijão na produção de grãos colhidos no Brasil é de apenas $4 \%$. A sua cultura é bem distribuida ao longo do ano por todo o país, sendo plantada tanto nos "fundos de quintal" para autoconsumo, como em escala comercial, em pequenas e médias propriedades, e mais recentemente, tem sido explorada em escala empresarial, obtendo-se produtividade três a cinco vezes superiores à média nacional (500 Kg/ha) (BANNO, 1994).
\end{abstract}

Em virtude da forte vulnerabilidade às condições climáticas desfavoráveis e aos ataques de pragas e doenças, há significativas variações na produção, de ano para ano. Entre as diversas doenças que atacam a cultura do feijoeiro, a mancha angular, causada pelo fungo Phaeoisariopsis griseola (Sacc.) Eerraris, considerada no passado como de importância secundária, vem crescendo, em intensidade e área, estando presente em todas as regiōes produtoras, com os maiores danos sendo causados no feijão da seca e no de inverno, irrigado por aspersão.

Segundo a literatura, essa doença vem causando danos em várias regióes do mundo. Nos Estados unidos (CARDONAALVAREZ \& WALKER, 1956) e na Colômbia (BARROS et alii, 
1958; SCHWARTz et alii, 1981), foram estimados danos na ordem de 50 e 40-80\%, respectivamente. No Brasil há poucos estudos sobre essa doença. Recentemente, alguns autores têm mostrado a importância que esta doença assume, reduzindo a produção dos cultivares mais plantados comercialmente, devido ao desfolhamento precoce dos feijoeiros. MORA-BRENES et aIii (1983) e SARTORATO \& RAVA (1992) estimaram perdas que variaram de 7 a $70 \%$, dependendo da maior ou menor suscetibilidade dos cultivares, das condições ambientais e da patogenicidade dos isolados. No entanto, esses dados são muito variáveis, não havendo consistência entre o nível de severidade de doença e os danos causados na produção.

Estimativas confiáveis dos prejuizos causados constituem-se num pré-requisito para o desenvolvimento de qualquer programa bem sucedido de controle de doenças, independente do método a ser utilizado (BERGAMIN EILHO, 1995). A determinação do prejuízo é necessária para que, em conjunção com o custo de controle, possa ser tomada uma decisão racional e econômica.

o presente trabalho teve como objetivo a quantificação de danos causados pela mancha angular no feijoeiro, nos cultivares Rosinha G-2 e carioca comum. 


\section{REVISÃO DE LITERATURA}

\subsection{A mancha angular do feijoeiro}

\subsubsection{Agente causal e ciclo de relações patógeno - hospedeiro}

A mancha angular do feijoeiro é causada pelo fungo Phaeoisariopsis griseola (Sacc.) Eerraris descrito e classificado inicialmente por Saccardo, em 1878, na Itália, como Isariopsis griseola. O agente causal pertence à subdivisão Deuteromycotina, ordem Moniliales, família Stilbaceae. Taxonomicamente apresenta os seguintes sinônimos: Graphium Iaxum Ell., Isariopsis laxa (Ell.) Sacc., Cercospora columnare EII. e Ev., Cercospora sthulmanni Henn. e Lindaumyces griseola Gonz. Frag. (LLANOS, 1957; FERRAZ, 1980).

O fungo apresenta esporos cinzas, retos ou levemente curvos, com 1 a 6 septos, sendo os com 3 septos mais comuns, variando de 43 a 68 micra de comprimento por 3 a 8 micra de largura, produzidos em feixes de 8 a 40 conidióforos pardo escuros, que se constituem em um grupo de hifas bem agregadas, mas nào unidas umas às outras e tendem a separar-se à medida que envelhecem, indicando que 
esta estrutura, na realidade, não é um corêmio típico (MILES, 1917; LLANOS, 1957; EERRAZ, 1980).

A sobrevivência entre estações de cultivo ocorre em restos de cultura na forma de conidio ou micélio dormente e em sementes contaminadas. A liberação e a disseminação dos esporos são favorecidas por condições de atmosfera seca e ventos secos, respectivamente. Os conidios germinam na superficie foliar e o tubo germinativo penetra através de estômatos, as hifas crescem intercelularmente através de células do mesófilo. À medida que se estabelece a necrose celular, o fungo se torna intracelular e se estende rapidamente até ser restringido pelos feixes vasculares.

Uma vez que a penetração ocorreu, o desenvolvimento da doença prossegue em condições atmosféricas relativamente secas e, após 9-12 dias, estromas são formados abundantemente em cavidades subestomatais. A esporulação ocorre durante períodos de alta umidade. Temperaturas ideais para a infeç̧ão e o desenvolvimento da doença variam de 16 a $28^{\circ} \mathrm{C}$, apresentando um ótimo a $24^{\circ} \mathrm{C}$ (CARDONA-ALVAREZ \& WALKER, 1956; CAMPOS \& ZAK, 1980; KIMATI, 1980; SAETTLER, 1991).

Os sintomas podem ocorrer em folhas, vagens, caule, ramos e pecíolos. As lesões foliares são pardas e angulosas, delimitadas por nervuras e, com a frutificação do fungo, assumem uma tonalidade acinzentada. A alta severidade da doença nas folhas tende a causar desfolha precoce. No caule, as lesões são alongadas, pardo-escuras, com tonalidade acinzentada quando se cobre de frutificaçoses do fungo. Nas vagens, as lesões são superficiais, de coloração castanho-avermelhada, quase circulares, com os bordos escuros, o tamanho das lesões pode ultrapassar $1 \mathrm{~cm}$ de diametro (LlLANOS, 1957; EERRAZ, 1980; KIMATI, 1980). No 
campo, os sintomas são geralmente observados logo após 'o florescimento ou quando as plantas se aproximam da maturação.

Segundo CARDONA-ALVAREZ \& WALKER (1956) o fator mais crítico no desenvolvimento de epidemias nos trópicos e nas zonas temperadas parece ser a umidade. O complexo climático mais favorável para o desenvolvimento de epidemias da doença, inclui temperaturas moderadas e alta umidade lou um filme de água em folhas e caules infectados) por 48 horas ou mais, alternando com períodos de baixa umidade e ação do vento.

\subsubsection{Controle da doença}

Apesar da sua freqüente ocorrência, a mancha angular na cultura do feijoeiro era considerada de importância econômica secundária, ocorrendo somente no final de ciclo. Atualmente, ela tem merecido maior atenção devido aos danos que vem causando, especialmente no feijão da seca e no feijão de inverno, irrigado por aspersão, reduzindo a produção dos cultivares mais plantados comercialmente, devido ao desfolhamento e maturação precoce dos feijoeiros (ISSA et aIii, 1982; MORA BRENES et alii, 1983; RODRIGUES et aIii, 1987; MENEZES, 1994).

As principais medidas de controle disponiveis atualmente são controle químico, rotaçăo de culturas por um periodo 6 meses até 2 anos, para decomposição de resíduos infectados, e utilização de variedades com algum nivel de resistència. Embora a taxa de transmissão do patógeno através da semente seja muito baixa, recomenda-se o seu tratamento químico com o produto benomyl, para evitax a 
introdução de novos patótipos em áreas nas quais os mesmos não ocorram (SARTORATO \& RAVA, 1994).

O controle químico curativo com os produtos registrados não tem sido eficiente nas condições da safra de inverno irrigadas por pivô central, devido ao longo período de incubação do fungo que varia entre 5 a 12 dias (MENEZES, 1994). Atualmente, tem se recomendado o controle preventivo com duas a três aplicações, dependendo do histórico da área. Os melhores resultados têm sido obtidos com triazóis, benzimidazóis, captan, estanho e mancozeb (ISSA et alii, 1982; RODRIGUES et aIii, 1987).

A utilização de cultivares com adequado nível de resistência pode proporcionar uma proteção adicional dentro de um sistema integrado de manejo da doença, embora, genótipos resistentes num local possam se comportar como suscetiveis em outro devido à variabilidade patogênica que - fungo apresenta (SARTORATO, 1989). O cultivar Aporé foi lançado recentemente como resistente à mancha angular (MENEZES, 1994). Segundo a literatura, parece haver diferentes tipos de resistência à mancha angular do feijoeiro, sendo em alguns casos recessiva e controlada por 2 ou 3 fatores independentes e em outros, dominante e governada por um único gene (BARROS et alii, 1958; CARDONAALVAREZ, 1962). 


\subsection{Avaliação de danos devido a doenças}

\subsubsection{Terminologia empregada}

As doenças de plantas foram inicialmente estudadas devido aos danos que causavam, mas ainda hoje são poucos os dados confiáveis de estimativas de danos disponíveis na Iiteratura. Essa falta de dados pode ter retardado o progresso do manejo de doenças de plantas mais do que qualquer outro fator isolado (JAMES, 1974).

Para um desenvolvimento de métodos de controle econômico e racional, seja através de controle químico, variedades resistentes, práticas culturais ou manejo integrado; não é suficiente afirmar que uma doença causa perda. A magnitude do dano deve ser avaliada, para poder ser correlacionada com o ganho obtido. Somente através da avaliação da relação doença-dano é possivel determinar as perdas econômicas devido a diferentes quantidades de doença (JAMES, 1974; JAMES \& TENG, 1979).

Una definição precisa dos termos utilizados pelos fitopatologistas faz-se necessária para chegar a um consenso de idéias. Desta forma, serão utilizados os conceitos citados por ZADOKS (1985) que define organismo nocivo como qualquer agente biológico que danifique uma plantação. Produção, como o produto mensurável de valor econômico de uma plantaçăo. Qualquer sintoma visivel causado por um organismo nocivo é chamado de injúria. Dano é uma reduça na qualidade ou quantidade da produça e perda é a reduçăo em retorno financeiro por unidade de área devido a organismos nocivos. 
$\mathrm{Na}$ definição, nível de dano econômico é o nível de organismo nocivo cujos beneficios advindos do controle se igualam aos custos gastos nesta operação. Esta terminologia criada pelos entomologistas pode ser confusa para os fitopatologistas, que criaram o termo equivalente, limiar de dano.

Desta forma, o controle integrado de doenças visa manter as doenças abaixo do limiar de dano, utilizando-se de métodos definidos antes da instalação da cultura, como, por exemplo, a escolha do cultivar, ou de métodos decididos durante o crescimento da cultura, como a escolha de um fungicida e a época de aplicação.

\subsubsection{Delineamentos experimentais para avaliação de}

\section{danos}

Um programa típico de avaliação de danos, envolve o estudo das relações entre doença e sua correspondente redução na produção, e é determinado experimentalmente em ensaios de campo com estudos detalhados do sistema patógeno-hospedeiro. Esse estudo abrange conhecimentos sobre quantificação de doença, epidemiologia da doença e estimativa de danos através da geração de dados para descrever a relação doença-dano.

o primeiro passo na pesquisa da quantificação de danos é a utilização de um método confiável de avaliaçào de doenças no patossistema em estudo. Embora doença seja usualmente definida como uma interferència anormal nos processos fisiológicos da planta, é raramente medida como um parametro fisiológico. Para efeito de quantificação de 
danos, dois métodos de avaliação de doenças têm sido utilizados: incidência e severidade (JAMES \& TENG, 1979).

Incidência, definida como a frequência de plantas ou partes de plantas doentes em uma população (JAMES, 1974), é um método de alta precisão e simplicidade. Dados obtidos por contagem são facilmente reproduzíveis, independente do avaliador. A limitação deste método para quantificação de danos reside no fato de seu uso estar limitado às doenças sistêmicas (murchas vasculares e algumas viroses) ou àquelas em que uma única infecção for suficiente para impedir a comercialização do produto (podridão de frutos e legumes).

Severidade de doença, definida como a porcentagem da área ou volume de tecido coberto por sintomas (JAMES, 1974) é talvez o método mais utilizado para avaliação de doenças foliares. O uso de escalas diagramáticas, representações ilustradas de uma série de plantas ou partes de plantas com sintomas em diferentes níveis de severidade, vem sendo amplamente adotado para estimax severidade de doença, com a vantagem de fácil comparação entre diferentes trabalhos. Outras ferramentas utilizadas para estimar severidade são as chaves descritivas e sensoriamento remoto. O estádio de desenvolvimento do hospedeiro deve também ser avaliado para poder ser correlacionado com o progresso da doença.

Para estimar os danos que as doenças causam é necessário encontrar a funçăo de dano que relaciona dano (D) com injúria (I) através da equação: $D=f(I)$. Para determinar essa função é necessária a realizaçăo de experimentos que têm como objetivo a geração de dados confiáveis para caracterizar a relação entre injúria, que nesse contexto pode ser traduzida como intensidade de doença (incidência ou severidade), e redução na produçăo e 
qualidade. Isso envolve experimentação com tratamentos sadios e outros com vários níveis de doença, para obter um conjunto de variáveis independentes (níveis de doença) que possa ser relacionado com um conjunto de variáveis dependentes (níveis de dano).

Entre os métodos mais utilizados para gerar dados, destacam-se o método da parcela experimental e, mais recentemente, o uso de plantas individuais vem sendo explorado (JAMES \& TENG, 1979; HAU et alii, 1980).

O método da parcela experimental, consiste na utilização de tratamentos pareados ou tratamentos múltiplos. Tratamentos pareados se utilizam de parcelas gêmeas, sadias e doentes, sendo que cada par origina um conjunto de dados com diferentes intensidades de doença e consequientes danos. Experimentos com tratamentos múltiplos se utilizam de dois ou mais niveis de intensidade de doença, sendo esses experimentos mais eficientes que os de parcelas pareadas (CAMPBELL \& MADDEN, 1990). A quantificação da produção deve ser feita através das mesmas técnicas de colheita utilizadas pelos produtores, visto que - objetivo da pesquisa é a determinação de danos sob condições normais de cultivo. O dano seria considerado como a redução da produção entre parcelas com diferentes níveis de doença e parcelas sadias, expresso usualmente em porcentagem (JAMES \& TENG, 1979 ).

A maior dificuldade neste método é manter, num mesmo ensaio, todos os fatores constantes, variando somente os niveis de doença. Múltiplos niveis de doença podem ser obtidos variando métodos de inoculaçăo ou proteça, cultivares ou locais. Plantas (parcelas) podem ser inoculadas em tempos e com freqüencias diferentes, e a concentraço do inóculo pode variar. pode-se utilizar 
fungicidas para variar os níveis de doença, variando dosagens, épocas, e número de aplicações. Outras técnicas que podem ser utilizadas são 0 uso de variedades com diferentes niveis de resistência, mas mesmas potencialidades de produção e a utilização de Iinhas isogênicas associadas com fungicidas (JAMES, 1974; MADDEN, 1983).

No método da planta individual, individuos sadios e doentes, encontrados em campo comercial ou experimental, substituem as parcelas. A doença é avaliada em um grande número de plantas $(50$ a 2000 plantas) com uma ampla faixa de niveis de severidade. As plantas são marcadas, avaliadas para intensidade de doença e colhidas quando atingirem a maturidade para se avaliar a produção. Cada planta é considerada como um dado para a análise de regressão (CAMPBELL \& MADDEN, 1990). As vantagens desse método são: utilização de epidemias naturais, variação completa no nível de intensidade da doença que pode ser conseguida durante uma única estação de cultivo e economia de tempo e espaço. A principal desvantagem do método decorre do fato dos modelos resultantes explicarem somente uma pequena quantidade da variação da produção devido a doença (baixo $\mathrm{R}^{2}$ ), pois existe uma diferença de produça inerente entre as plantas (JAMES \& TENG, 1979).

\subsubsection{Modelos tradicionais de avaliação de danos}

Modelos matemáticos săo necessários para sintetizar a grande quantidade de dados gerados em experimentos que estudam a relaçăo doença-dano e alcançar uma interpretaça relativamente simples (CAMPBELL \& MADDEN, 1990). Os 
modelos descritos na literatura são geralmente empíricos, derivados de dados obtidos em levantamentos de campo ou levantamentos regionais. A maioria das equações que têm sido desenvolvidas para descrever modelos de doença-dano é obtida por regressão, onde a porcentagem de dano é a variável dependente e um ou mais valores de doença são as variáveis independentes. Há muitos tipos de modelos que podem ser utilizados para descrever essa relação, entre eles são citados os modelos de ponto crítico, de múltiplos pontos, integrais, superficie resposta e sinópticos (JAMES \& TENG, 1979; MAIN, 1977; CAMPBELL\& MADDEN, 1990). Esses modelos diferem entre si nas caracteristicas epidêmicas que são utilizadas para prever dano.

Os modelos de ponto crítico implicam na existência de um ponto crítico, onde a cultura é particularmente sensivel à doença, e a intensidade de doença presente está altamente correlacionada com o dano futuro, desta forma, uma só variável independente reflete, com maior ou menor precisão, toda a epidemia. Esses modelos têm sido utilizados com sucesso para culturas de gramineas (LARGE, 1966), onde a epidemia ocorre tardiamente no ciclo de cultivo, próxima ao enchimento de grãos.

Já nos modelos de múltiplos pontos, a estimativa de danos é baseada numa sequiencia de avaliações durante a estação de cultivo. Esse tipo de modelo irá ser mais aplicado do que os modelos de ponto critico em situaçoes onde o acúmulo de produção ocorre durante um periodo relativamente Iongo ou a taxa de progresso da doença é altamente variável. O dano é relacionado com a intensidade de doença observada a cada tempo através de uma equaçăo de regressăo múltipla que apresenta como forma geral: $Y=b_{1} X_{1}$ $+b_{2} X_{2}+\ldots \ldots b_{n} X_{n}$ onde $Y$ é a porcentagem de danos na 
produção e $X$ é a intensidade de doença no tempo $n$, esse modelo foi aplicado com sucesso para o patossistema batataPhytophthora infestans por JAMES et alii. (1972).

Modelos integrais relacionam danos com alguma variável que represente a totalidade de uma epidemia como, por exemplo, a área sob a curva de progresso da doença (area under the disease progress curve - AUDPC), proposto inicialmente por VANDERPLANK (1963).

Os modelos de superficie resposta estimam dano a partir de duas entradas, seguindo a equação geral: $\frac{\circ}{\circ}$ Dano = $f(X, T)$, onde $X$ é usualmente a severidade de doença $e T$, o estádio de desenvolvimento do hospedeiro.

Modelos sinópticos, diferentemente dos demais, abordam múltiplos fatores limitantes da produção, bióticos ou abióticos. No sistema de produção atual, este modelo é mais apropriado por ser comum a ocorrência concomitante de diferentes organismos nocivos.

\subsubsection{Avaliação de danos através da área foliar} fotossintetizante

A correlação entre dados de produção e intensidade de doença, obtida através dos modelos descritos anteriormente, dependendo do patossistema estudado, nem sempre leva a resultados satisfatórios, uma vez que a resposta fisiológica da cultura à doença ná é considerada, ignorando fatos como época em que a doença incidiu na cultura, desfolha e a área foliar das plantas (WAGGONER \& BERGER, 1987 ). 
- parâmetro área foliar total é o mais comumente utilizado por agrônomos e fisiologistas, para descrever e explicar diferenças em potencial de crescimento de plantas submetidas a diferentes tratamentos, e é freqüentemente correlacionado, assim como índice de área foliar ou duração de área foliar, com produção (GAUNT, 1981).

WAGGONER \& BERGER (1987) alegam que a produção ou matéria seca de uma planta é função em grande parte da fotossintese que ocorre nas folhas, desta forma, doenças reduzem a produção através da redução na taxa fotossintética das folhas, uma vez que diminuem a quantidade de tecido foliar fotossinteticamente ativo.

Para certas culturas, a duração da área foliar sadia tem se mostrado um parâmetro mais relevante para a produção do que tecido doente. WAGGONER \& BERGER (1987) propuseram a variável duração da área foliar sadia (healthy leaf area duration - HAD) que é a integral do indice de área foliar sadia da cultura durante a estação de crescimento, como principal indicadora de produção. Ela pode ser calculada pela fórmula:

$$
H A D=\sum_{i=1}^{n_{0}-1}\left[L A I_{i}\left(1-x_{i}\right)+L A I_{i+1}\left(1-x_{i+1}\right)\right] / 2\left(t_{i+1}-t_{i}\right)
$$

onde $x$ representa o tecido doente, e desta forma, (1-x) representa o tecido sadio, LAIi é o indice de área foliar (leaf area indice - LAI) no tempo $t_{i}$.

Esses autores propuseram ainda que a produção seria melhor correlacionada a uma varíavel que leva em conta a quantidade de luz realmente absorvida pela folhagem, a absorção de luz da área foliar sadia (healthy leaf area absorption - HAA), que de forma análoga, é a integral da quantidade de insolação absorvida pela área foliar sadia, 
considerando a lei de Beer para expressar a transmissão da insolação $I\left(\mathrm{MJm}^{-2}\right)$ através da folhagem, onde a fração absorvida $f$ é dada por

$$
f=(1-\exp (-k L A I))
$$

sendo $k$ o coeficiente de extinção (valor próximo a um para plantas com folhas horizontais e ao redor de 0,3 para plantas com folhas eretas). Desta forma, a variável HAA pode ser calculada por:

$$
H A A=\sum_{i=1}^{n_{1}-1} I\left[\left(1-x_{i}\right)\left(1-\exp \left(-k L A I_{i}\right)\right)+\left(1-x_{i+1}\right)\left(1-\exp \left(-k L A I_{i+1}\right)\right)\right] / 2\left(t_{i+1}-t_{i}\right)
$$

Estas variáveis foram utilizadas com sucesso por esses autores para culturas como amendoim, batata, milho e trigo.

Seguindo essa linha de pensamento, vários trabalhos vêm mostrando que a produção de culturas doentes está diretamente relacionada com a área foliar verde em um determinado estádio de crescimento (LIM \& GAUNT, 1986), com a duração da área foliar (ROTEM et alii, 1983; MADEIRA et alii, 1988), ou com a quantidade acumulada de radiação interceptada pela área foliar verde da cultura (HAVERKORT \& BICAMUMPAKA, 1986; WAGGONER \& BERGER, 1987).

Desta forma, modelos que substituem a intensidade de doença por duração da área foliar sadia (HAD) ou absorção de luz da área foliar sadia (HAA) estão permitindo um maior entendimento das relações entre doenças e danos na produção. Esses modelos nos dão a idéia sobre o tamanho das plantas, a quantidade de radiação global absorvida e o efeito das doenças sobre a folhagem das plantas. 


\section{MATERIAL E MÉTODOS}

Com o objetivo de obter dados para o estabelecimento de uma função de dano ocasionado pela mancha angular (Phaeoisariopsis griseola) foram realizados dois ensaios de campo, nos anos de 1993 e 1994, na área experimental do Departamento de Fitopatologia da ESALQ/USP, em Piracicaba.

Para o primeiro plantio, realizado em 05/março/1993, utilizou-se o cultivar Carioca comum, onde foram plantadas 15 parcelas formadas por 4 linhas de 5 metros $\left(10 \mathrm{~m}^{2}\right)$. No plantio de 14/abril/1994, utilizou-se o cultivar Rosinha G2, constituindo-se o ensaio de 16 parcelas de 4 linhas por 5 metros $\left(10 \mathrm{~m}^{2}\right)$.

O plantio foi realizado com espaçamento de 0,5 metro entre Iinhas e uma densidade de semeadura de 12 plantas por metro linear. As culturas receberam os tratos culturais normais de campos comerciais, incluindo adubaçōes de plantio e cobertura, pulverizações contra mosca branca, capinas e suplementação hídrica por irrigação, quando necessário.

A metodologia utilizada foi a de plantas individuais (HAU et alii, 1980), marcando-se 6 plantas nas duas linnas centrais de cada parcela, totalizando-se 90 plantas para o primeiro ensaio e 96 para o segundo. As plantas foram 
marcadas com fita plástica colorida na etapa de desenvolvimento V2/V3 da escala descrita por Gepts \& Eernandéz ${ }^{1}$, citada por EANCELLI (1990), buscando-se marcar plantas homogêneas dentro do campo. Nesta mesma data foram iniciadas as avaliações para área foliar sadia e severidade de doença.

Para obter diferentes níveis de doença, utilizou-se diferentes concentrações de inóculo inicial nas parcelas. As pulverizações com suspensões de conídios de Phaeoisariopsis griseola foram iniciadas no etapa de desenvolvimento $\mathrm{V} 2 / \mathrm{V} 3$ e foram feitas com o auxílio do equipamento UBV (ultra baixo volume). Para o primeiro ensaio, foram feitas 2 inoculações em um intervalo de 12 dias, e para o segundo, 5 inoculações em intervalos semanais. As inoculações foram realizadas nos diferentes sentidos do campo (horizontal e vertical) como pode ser visualisado nas Eiguras 01 e 02 . As inoculações recebidas pelas diferentes parcelas, para os cultivares Carioca e Rosinha estão detalhadas nas Tabelas 01 e 02 , respectivamente.

Para obter plantas sadias (com nível zero de severidade) utilizou-se de pulverizações semanais de uma das parcelas com o fungicida Benlate 500 (benomyl) na dosagem de $0,5 \mathrm{~kg} / \mathrm{ha}$.

\footnotetext{
'Gepts, P. \& EERnANoez, E. Etapas de desarrolo de la planta de frijol comum (Phaseolus whigaris, L.). Cali, Colombia, 1982. Lop. (mimeografido).
} 


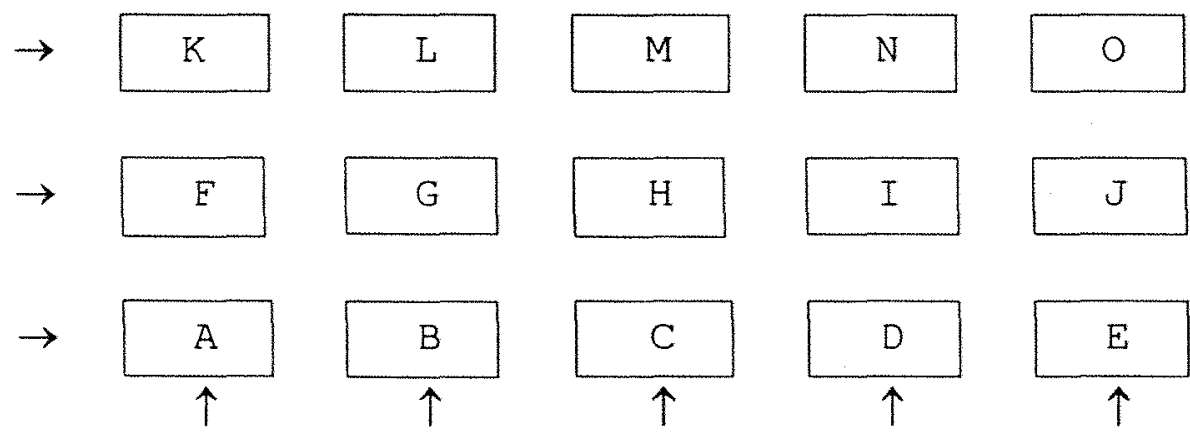

Eigura 01. Inoculações cruzadas realizadas no ensaio de campo para o cultivar Carioca.

Tabela 01 . Concentrações de inóculo aplicadas nas parcelas do cultivar Carioca.

\begin{tabular}{|c|l|l|l|l|l|l|l|}
\hline Parcela & Planta & \multicolumn{2}{|c|}{ inoculações } & Parcela & Planta & \multicolumn{2}{|c|}{ inoculações } \\
$\mathbf{1}^{\mathbf{a}}$ & & $\mathbf{2}^{\mathbf{a}}$ & & & & $\mathbf{2}^{\mathbf{a}}$ \\
\hline $\mathrm{A}$ & $1-6$ & $10^{5}$ & $10^{5}$ & $\mathrm{I}$ & $49-54$ & $10^{4}$ & $10^{2}$ \\
\hline $\mathrm{B}$ & $7-12$ & $10^{5}$ & $10^{4}$ & $\mathrm{~J}$ & $55-60$ & $10^{4}$ & $10^{1}$ \\
\hline $\mathrm{C}$ & $13-18$ & $10^{5}$ & $10^{3}$ & $\mathrm{~K}$ & $61-66$ & $10^{2}$ & $10^{5}$ \\
\hline $\mathrm{D}$ & $19-24$ & $10^{5}$ & $10^{2}$ & $\mathrm{~L}$ & $67-72$ & $10^{2}$ & $10^{4}$ \\
\hline $\mathrm{E}$ & $25-30$ & $10^{5}$ & $10^{1}$ & $\mathrm{M}$ & $73-78$ & $10^{2}$ & $10^{3}$ \\
\hline $\mathrm{F}$ & $31-36$ & $10^{4}$ & $10^{5}$ & $\mathrm{~N}$ & $79-84$ & $10^{2}$ & $10^{2}$ \\
\hline $\mathrm{G}$ & $37-42$ & $10^{4}$ & $10^{4}$ & $\mathrm{O}$ & $85-90$ & 0 & 0 \\
\hline $\mathrm{H}$ & $43-48$ & $10^{4}$ & $10^{3}$ & & & & \\
\hline
\end{tabular}




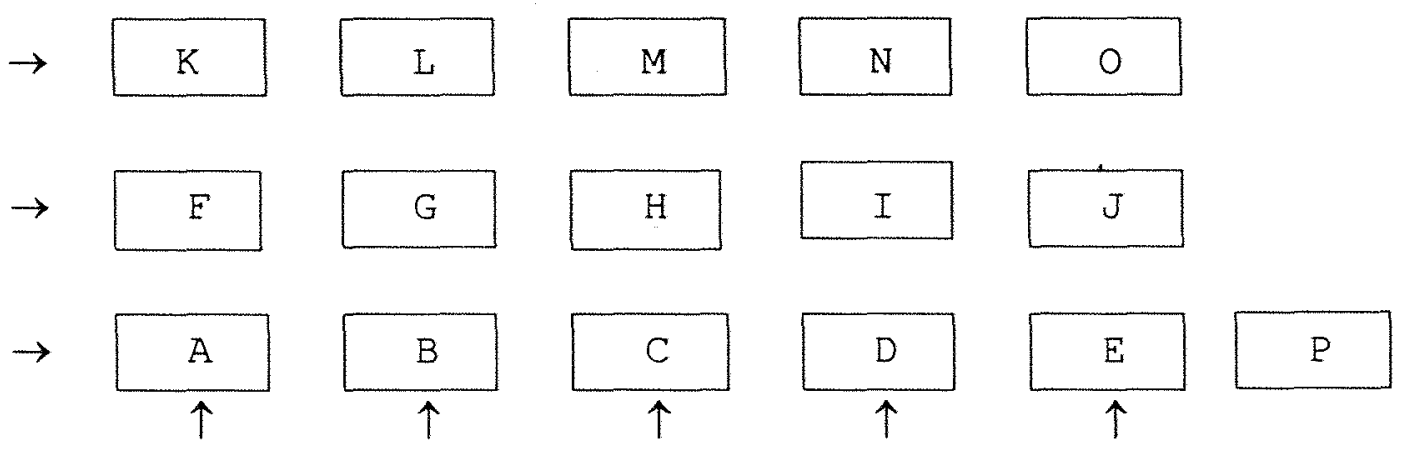

Figura 02. Inoculações cruzadas realizadas no ensaio de campo para o cultivar Rosinha.

Tabela 02. Concentrações de inóculo aplicadas nas parcelas do cultivar Rosinha.

\begin{tabular}{|c|c|c|c|c|c|c|}
\hline Parcela & Planta & \multicolumn{5}{|c|}{ inoculaçóes } \\
& & $\mathbf{1}^{\mathbf{a}}$ & $\mathbf{2}^{\mathbf{a}}$ & $\mathbf{3}^{\mathbf{a}}$ & $\mathbf{4}^{\mathbf{a}}$ & $\mathbf{5}^{\mathbf{a}}$ \\
\hline $\mathrm{A}$ & $1-6$ & $10^{5}$ & $10^{3}$ & $10^{4}$ & $10^{2}$ & $10^{4}$ \\
\hline $\mathrm{B}$ & $7-12$ & $10^{4}$ & $10^{3}$ & $10^{3}$ & $10^{2}$ & $10^{3}$ \\
\hline $\mathrm{C}$ & $13-18$ & $10^{3}$ & $10^{3}$ & $10^{2}$ & $10^{2}$ & $10^{2}$ \\
\hline $\mathrm{D}$ & $19-24$ & $10^{2}$ & $10^{3}$ & $10^{1}$ & $10^{2}$ & $10^{1}$ \\
\hline $\mathrm{E}$ & $25-30$ & $10^{1}$ & $10^{3}$ & 0 & $10^{2}$ & 0 \\
\hline F & $55-60$ & $10^{5}$ & $10^{4}$ & $10^{4}$ & $10^{3}$ & $10^{4}$ \\
\hline $\mathrm{G}$ & $49-54$ & $10^{4}$ & $10^{4}$ & $10^{3}$ & $10^{3}$ & $10^{3}$ \\
\hline $\mathrm{H}$ & $43-48$ & $10^{3}$ & $10^{4}$ & $10^{2}$ & $10^{3}$ & $10^{2}$ \\
\hline $\mathrm{I}$ & $37-42$ & $10^{2}$ & $10^{4}$ & $10^{1}$ & $10^{3}$ & $10^{1}$ \\
\hline $\mathrm{J}$ & $31-36$ & $10^{1}$ & $10^{4}$ & 0 & $10^{3}$ & 0 \\
\hline $\mathrm{K}$ & $61-66$ & $10^{5}$ & $10^{5}$ & $10^{4}$ & $10^{4}$ & $10^{4}$ \\
\hline $\mathrm{L}$ & $67-72$ & $10^{4}$ & $10^{5}$ & $10^{3}$ & $10^{4}$ & $10^{3}$ \\
\hline $\mathrm{M}$ & $73-78$ & $10^{3}$ & $10^{5}$ & $10^{2}$ & $10^{4}$ & $10^{2}$ \\
\hline $\mathrm{N}$ & $79-84$ & $10^{2}$ & $10^{5}$ & $10^{1}$ & $10^{4}$ & $10^{1}$ \\
\hline $\mathrm{O}$ & $85-90$ & $10^{1}$ & $10^{5}$ & 0 & $10^{4}$ & 0 \\
\hline $\mathrm{P}$ & $91-96$ & 0 & 0 & 0 & 0 & 0 \\
\hline
\end{tabular}


O inóculo foi obtido a partir da multiplicação de um isolado do fungo proveniente de plantas cultivadas na Estação Experimental do Instituto Agronômico do Paraná / Londrina, em meio de suco de tomate (DALLA PRIA \& BERGAMIN EILHO, 1995). As placas com o isolado eram incubadas por 15 dias em estufa, a $24^{\circ} \mathrm{C}$ e escuro. Após 15 dias, adicionavase $10 \mathrm{ml}$ de água por placa e o fungo era suspenso com pincel. Essa suspensão era filtrada e se adicionava 1 gota de tween 80 por Iitro de suspensão. A concentração do inóculo era avaliada com o auxilio de uma câmara de Neubauer. Foram utilizadas suspensões com a concentração de $10^{5}, 10^{4}, 10^{3}, 10^{2}$ e $10^{1}$ conídios/ml, obtidas por diluição em série a partir da suspensão mais concentrada.

As avaliações foram realizadas a partir do inicio das inoculações em intervalos médios semanais, anotando-se a área foliar e a severidade da doença para todas as folhas das plantas marcadas, e o estádio de crescimento do hospedeiro também era avaliado. A avaliação da área foliar era feita medindo-se a maior largura do folíolo central de cada folha da planta marcada. Essa largura (I) foi posteriormente correlacionada com a área total da folha através da equação $Y=\left(2,137094^{*} L^{1,96418}\right)-2,701269\left(\mathrm{R}^{2}=0,95\right)$ determinada por IAMAUTI (1995).

Para avaliação da severidade, foi elaborada uma escala diagramática (Eigura 03) seguindo-se as recomendações de JAMES (1974) quanto à lei de WeberEechner, segundo a qual a vista humana responde a estímulos que crescem em escala logaritmica, e quanto aos limites inferior e superior que devem estar dentro dos limites observados em condições naturais de infecçăo. Deste modo, a escala elaborada neste trabalho, com 9 níveis de 
severidade, teve como limites inferior e superior 0,2 e $30,4 \%$ de área doente, respectivamente. Os níveis intermediários foram calculados segundo o modelo logístico (HORSEALL \& BARRATT, 1945).
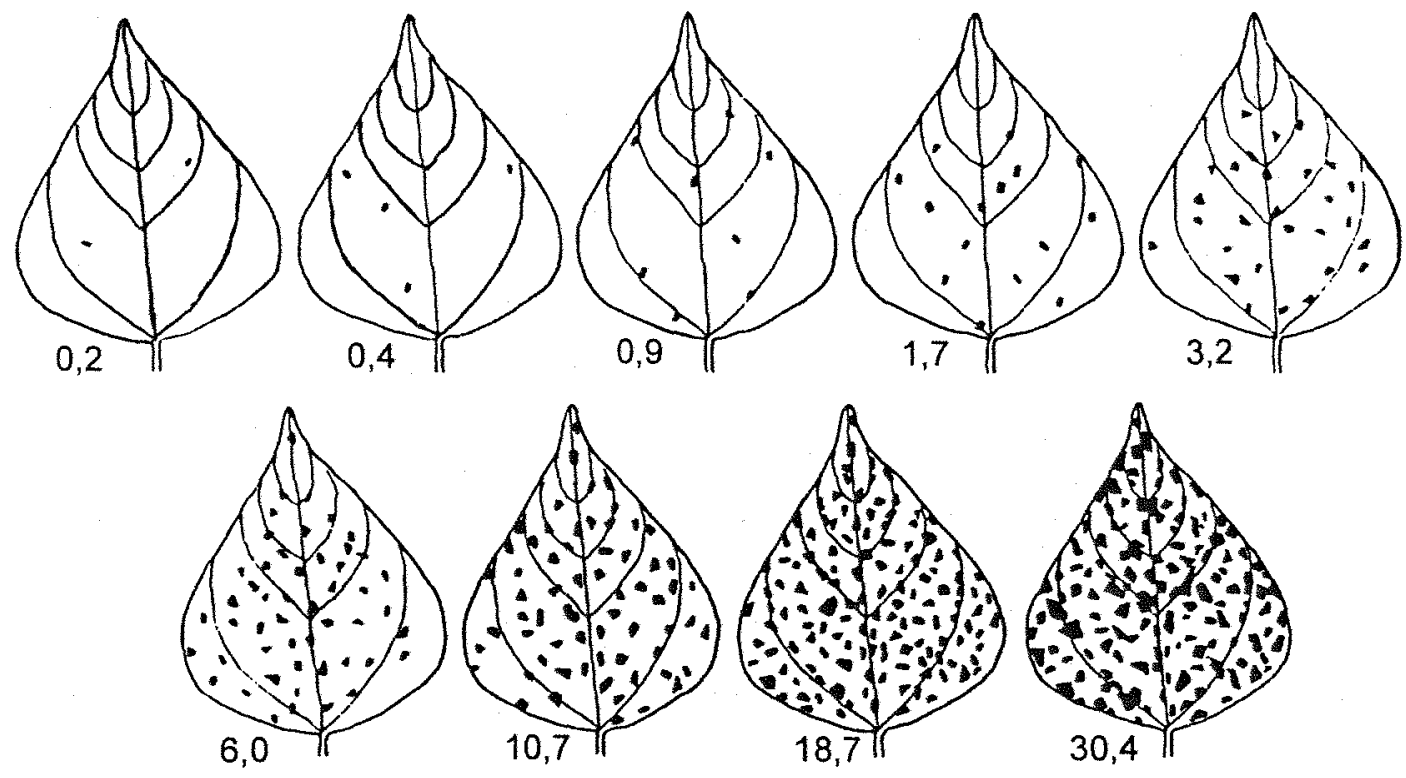

Figura 03. Escala diagramática de severidade (porcentagem de área foliar afetada) da mancha angular do feijoeiro.

A escala foi validada por 5 pessoas, através da avaliação visual de 90 figuras representando folílos de feijoeiro com diferentes níveis de severidade de mancha angular. Essas mesmas figuras tiveram sua severidade real determinada com o auxilio do medidor de área foliar LI 3000, na Estação Experimental do Instituto Agronômico do Paraná / Londrina. Da comparação dos dados estimados pelos 
avaliadores (medidos com a escala) com os dados reais de severidade (medidos com o medidor de área foliar LICOR), verificou-se que a avaliação foi acurada e precisa. O erro na estimativa da severidade, para todos avaliadores, foi sempre inferior a 10\% (GODOY et alii, 1995).

No final do ciclo da cultura, as plantas marcadas foram colhidas individualmente $e$ foram avaliadas as seguintes variáveis de produção: número de vagens por planta, peso total dos grãos (g), número de sementes por vagem e peso de 100 sementes.

Os dados obtidos através das avaliações de área foliar e severidade foram utilizados para o cálculo da área foliar total por planta (somatória das áreas individuais de cada folha) e área total doente, com o auxílio do programa Quattro-Pro.

A severidade estimada em porcentagem foi transformada em tecido doente $\left(\mathrm{cm}^{2}\right)$ para cada folha, e sua somatória resultou na área total doente.

A análise estatística dos dados com o programa Statistica foi realizada através de regressões lineares entre as variáveis de doença e de produção e entre a área foliar e as variáveis de produção. Através de regressões, - programa acusou a ocorrência de possiveis "outliers", ou seja, plantas cujos residuos estavam fora do intervalo \pm 2 vezes o desvio padrão, sendo essas plantas eliminadas da planilha final.

Para se realizar o ajuste dos dados a um dos modelos descritos na literatura, foram calculadas as variáveis AUDPC (área sob a curva de progresso da doença), AULAPC (área sob a curva de progresso da área foliar), HAD (duração do tecido sadio) e HAA (absorção do tecido sadio). 
A variável AUDPC foi calculada integrando-se a curva de progresso da doença para cada planta, através da Eórmula:

$$
A U D P C=\sum_{i}^{n-1}\left(\frac{x_{i}+x_{i+1}}{2}\right)\left(t_{i+1}-t_{i}\right)
$$

onde, $n$ é o número de avaliações, $x$ é a proporção de doença e $\left(t_{i+1}-t_{i}\right)$ é o intervalo entre duas avaliações consecutivas.

De maneira semelhante, calculou-se a variável área sob a curva de progresso da área foliar (area under the leaf area progress curve - AULAPC), que é a integral da curva de progresso da área foliar, para cada planta.

Para o cálculo da variável HAD foi necessário estimar o índice de área foliar (LAI), dividindo-se a área foliar total de cada planta pela área ocupada por planta 10.05 $\mathrm{m}^{2}$ ). Após o cálculo do LAI, foi possível calcular a variável HAD através da equação:

$$
H A D=\sum_{i=1}^{n_{0}-1}\left[L A I_{i}\left(1-x_{i}\right)+L A I_{i+1}\left(1-x_{i+1}\right)\right] / 2\left(t_{i+1}-t_{i}\right)
$$

A variável HAA foi calculada através da equação:

$$
H A A=\sum_{i=1}^{n_{0}-1} I\left[\left(1-x_{i}\right)\left(1-\exp \left(-k L A I_{i}\right)\right)+\left(1-x_{i+1}\right)\left(1-\exp \left(-k L A I_{i+1}\right)\right)\right] / 2\left(t_{i+1}-t_{i}\right)
$$

Os dados de radiação global (I) foram obtidos na estação meteorológica da ESALQ/USP e transformados de cal $/ \mathrm{cm}^{2}$ dia para MJ. Eoram utilizados os valores médios para os intervalos de avaliações. Os valores diários de radiação global para o período de avaliaçóes dos dois cultivares encontram-se no Apêndice 01. Foi utilizado $k=$ 0,7 (MADEIRA et 11 i., 1988; MIGLIORANZA, 1992). 


\section{RESULTADOS E DISCUSSÃO}

\subsection{Avaliação de danos causados pela mancha angular no cultivar Rosinha}

A distribuição da severidade de mancha angular lem AUDPC) obtida nas plantas marcadas no campo, pode ser vista na Eigura 04. Obteve-se plantas com diferentes níveis de severidade (AUDPC variando entre 0 e 260 unidades de área), embora a maioria delas encontra-se na faixa de 0 a 80 unidades de AUDPC. Estes diferentes niveis de severidade são necessários para que se obtenha uma função de dano, onde diferentes níveis de doença devem ser correlacionados à produção correspondente.

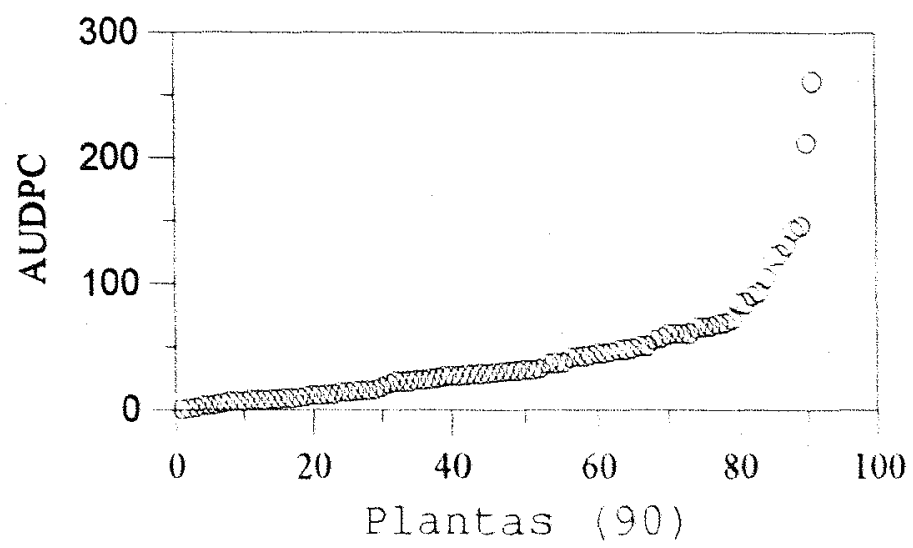

Eigura 04. Distribuição da severidade (em AUDPC) obtida nas plantas do cultivar Rosinha marcadas no campo 
Nas Eiguras 05 e 06 pode-se observar o progresso da área foliar e da severidade de mancha angular em relação à produção $(g)$ e ao número de vagens, respectivamente. Os primeiros sintomas foram observados entre a segunda $e$ terceira avaliação $(7$ a 14 dias após a primeira inoculação), confirmando o período de incubação do fungo que varia entre 9-12 dias (CARDONA-ALVAREZ \& WALKER, 1956). Nessa época, o feijão encontrava-se na fase reprodutiva $R_{6}$ (primeira flor aberta em 50\% das plantas). A partir desta data pôde ser observado o aumento da severidade da doença progressivamente até a última avaliação. Com relação à área foliar, o valor máximo obtido no ensaio foi observado aos 49 dias após o plantio, passando a decrescer, a partir dessa data. Este decréscimo foi, em parte, devido à desfolha causada pela severidade de doença, como será discutido mais tarde.

A severidade máxima alcançada foi de $30 \%$, em uma única planta. Uma característica observada neste ensaio, e já descrita na literatura por MORA-BRENES (1983), foi o fato de que quando a severidade nas folhas atingia 20-25\%, ocorria uma clorose, seguida de necrose e queda. Como neste ensaio as avaliações da severidade de doença foram baseadas na estimativa da área foliar coberta por lesões, não se levando em consideração a desfolha causada pela doença, pode-se dizer que a quantidade de doença foi subestimada, uma vez que as folnas doentes que caiam nào foram contabilizadas no cálculo da AUDPC final de cada planta. 


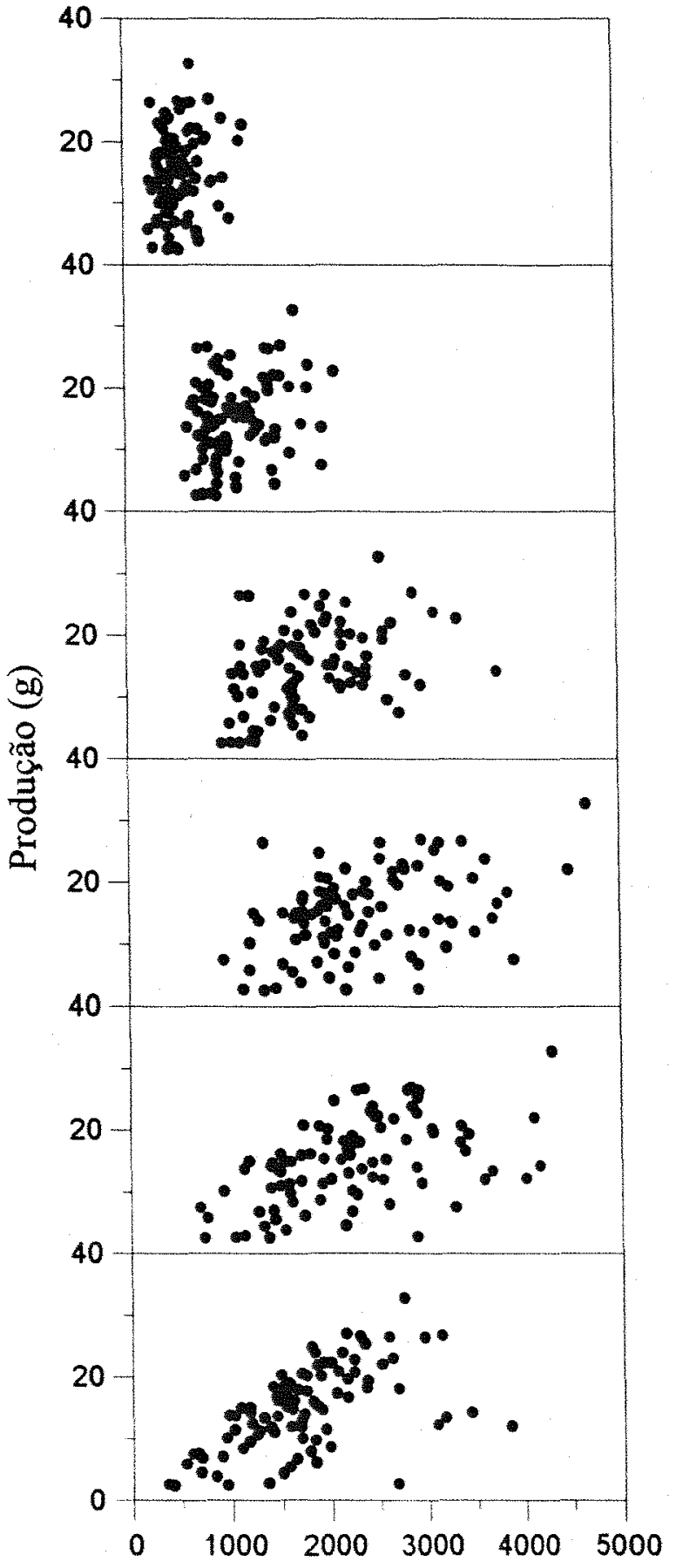

Área foliar $\left(\mathrm{cm}^{2}\right)$

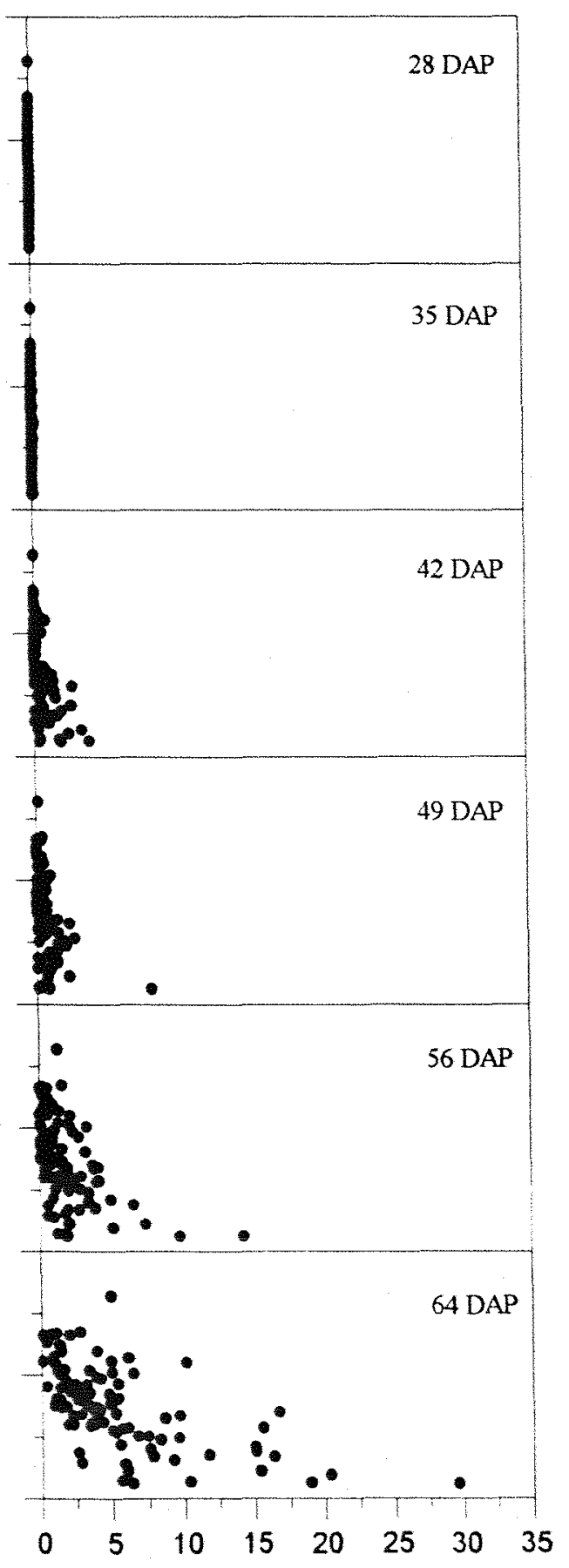

Severidade $(\%)$

Figura 05. Relação entre área foliar do feijoeiro $\left(\mathrm{cm}^{2}\right)$ e severidade $\left(\frac{g}{3}\right)$ com a produçăo $(g)$, em seis avaliações (cultivar Rosinha). 

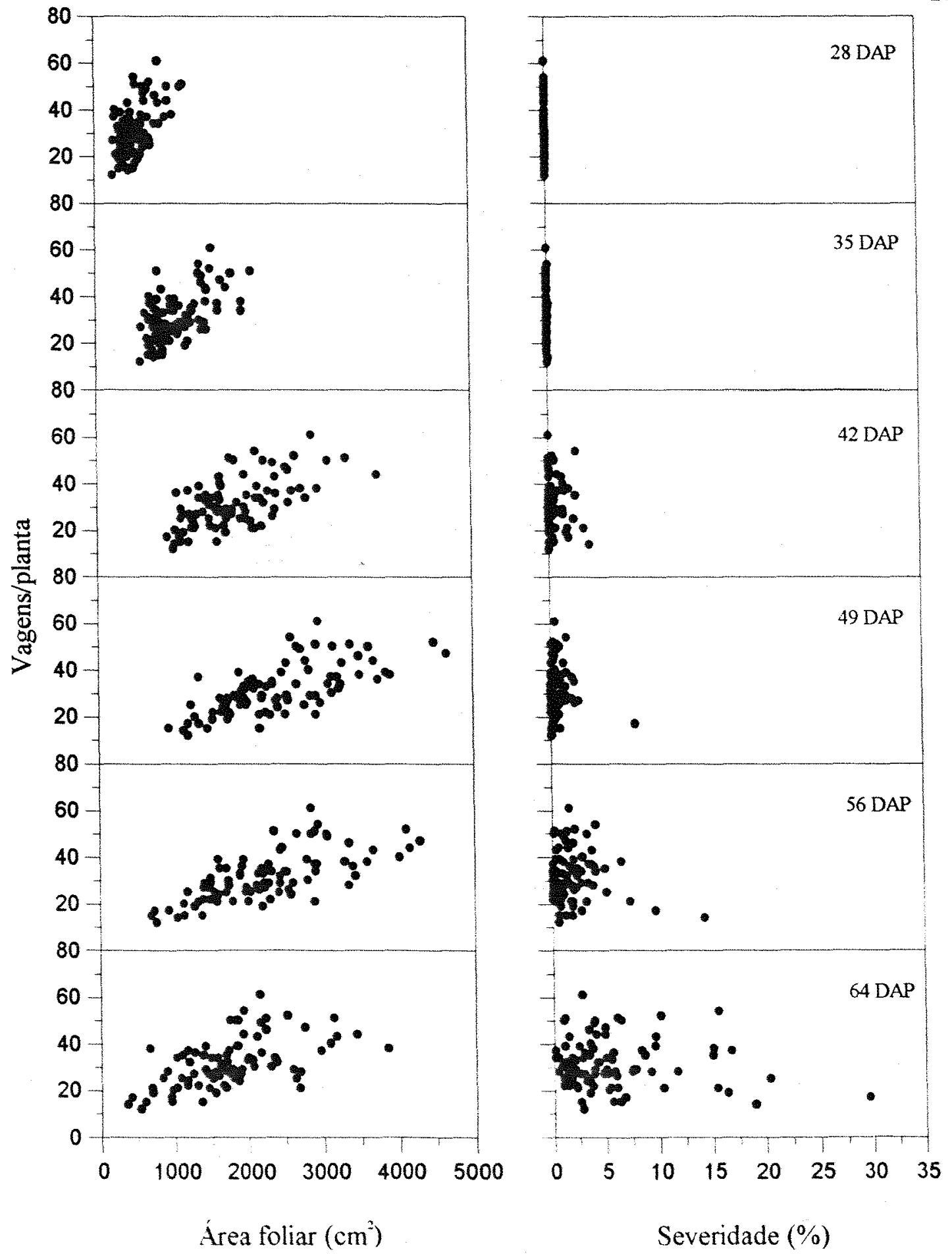

Eigura 06. Relação entre área foliar do feijoeiro $\left(\mathrm{cm}^{2}\right)$ e severidade $\left(\frac{0}{\partial}\right)$ com $O$ número de vagens por planta, em seis avaliações (cultivar Rosinha). 
Neste ensaio conseguiu-se variar o nivel de severidade, obtendo-se os dois extremos, plantas sadias e plantas com severidade máxima, e vários níveis intermediários. Valores altos de severidade, no entanto, foram raros, observados para poucas plantas apenas na última avaliação.

As variáveis AUDPC, AULAPC, HAD e HAA, calculadas conforme descrito no item Materiais e métodos, foram correlacionadas com as variáveis de produção. Para as variáveis dependentes produção (g) (Eigura 07a) e número de vagens por planta (Eigura 08a) não foi encontrada correlação com AUDPC. Para as quatro plantas cujos valores de AUDPC foram superiores a 120, a produção foi sempre pequena (menor que 5 gramas). No entanto, tal nível de produção foi também obtido em plantas com AUDPC ao redor de 50. A variação da produção foi independente da severidade de doença medida em AUDPC. A justificativa para este comportamento foi enunciada por WAGGONER \& BERGER (1987) que citaram que a variável AUDPC não nos fornece informação a respeito do tamanho e duração da área foliar da planta, e da insolação absorvida por essa área foliar. Desta forma, plantas com mesma severidade, mas com área foliar diferente apresentam diferentes potenciais de produção.

No entanto, SARTORATO \& RAVA (1992), estudando a influência do cultivar e do número de inoculaçóes na severidade da mancha angular e nas perdas na produça do feijoeiro comum, utilizando-se do método da parcela experimental, obtiveram uma correlaçăo negativa entre severidade da doença e rendimento $\left(R^{2}=-0,89\right)$. LANTER (1990) encontrou uma correlação positiva $\left(R^{2}=0,77\right)$ entre AUDPC e porcentagem de reduçăo na produção quando estudava 
a epidemiologia da mancha angular do feijoeiro em monoculturas e em plantio intercalado de feijão - milho. Os resultados encontrados por esses autores são contrários aos obtidos neste trabalho, possivelmente pela diferença no delineamento experimental (método da parcela) e na avaliação da severidade da doença.

A falta de correlação entre severidade de doença e produção, encontrada no ensaio com o cultivar Rosinha, tem sido observada na literatura para diversos patossistemas (ROTEM et aIii, 1983; LIM \& GAUNT, 1986; NUNES, 1994). Esses autores obtiveram um maior sucesso quando utilizaram as variáveis HAA e área foliar verde para correlacionar com danos.

O mesmo fato pode ser observado nas Eiguras 07b-d e 08b-d, onde as variáveis que substituem doença por área foliar (AULAPC), duração da área foliar sadia (HAD) ou ainda, absorção da área foliar sadia (HAA), apresentaram uma correlação positiva com os parâmetros de produção, embora o coeficiente de determinação encontrado seja baixo. Os baixos valores de $\mathrm{R}^{2}$ são consequência da alta variação de produção inerente das plantas, apontada como um fator desvantajoso nos modelos que utilizam o método de plantas individuais (JAMES \& TENG, 1979).

Os baixos coeficientes de determinação encontrados poderiam ser também explicados pelo fato dessas variáveis considerarem o efeito da doença somente como uma reduça no tecido foliar disponivel. Para alguns patossistemas, como Phytophthora infestans em batata, essa afirmaçăo já foi comprovada (van OIJEN, 1990). No entanto, além da redução no tecido foliar sadio, as doenças podem afetar também a eficiência de utilizaçăo da radiaçăo interceptada para o crescimento da cultura (JOHNSON, 1987). Desta forma, 
seriam necessários estudos mais avançados sobre o efeito do patógeno Phaeoisariopsis griseola na fotossintese de folhas de feijoeiro, para avaliar se o efeito da doença é devido somente à redução de tecido foliar.
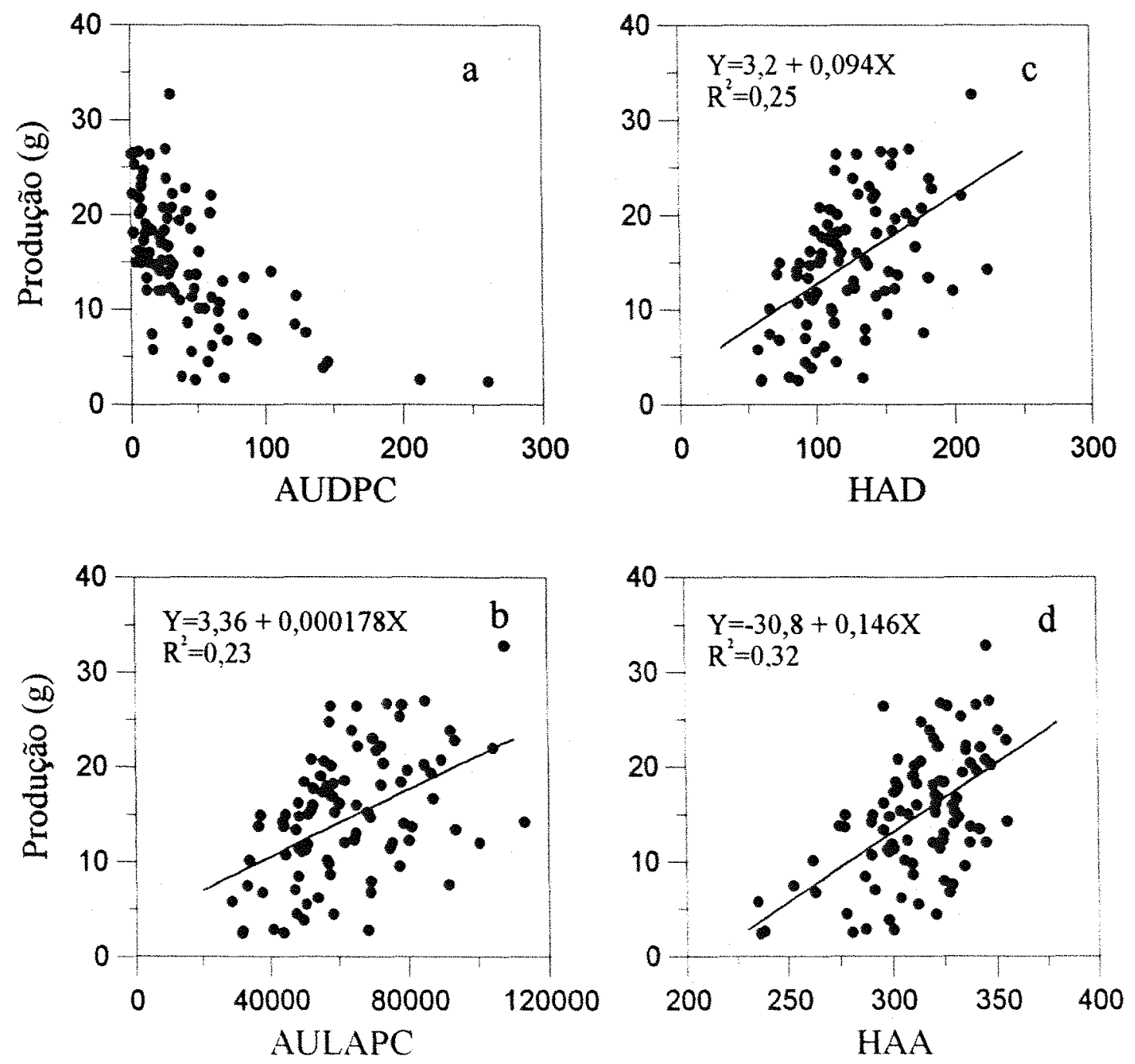

Eigura 07. Relação entre as variáveis AUDPC (a), AULAPC (b), HAD (c) e HAA (d), e produçăo (gramas) para o cultivar Rosinha. 

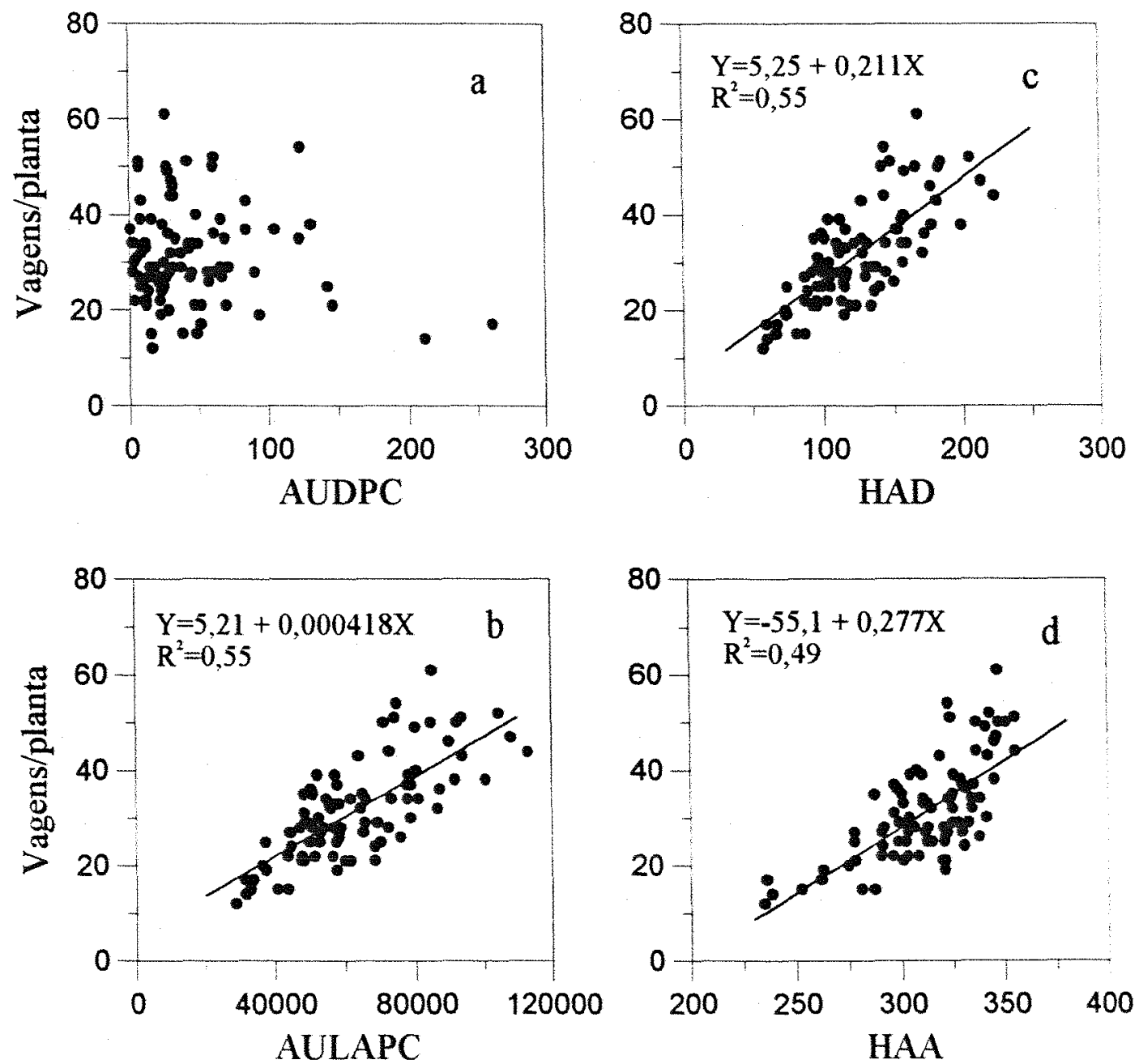

Eigura 08. Relação entre as variáveis AUDPC (a), AULAPC (b), HAD (c) e HAA (d), e número de vagens por planta para o cultivar Rosinha. 
Uma forma de "corrigir" esse baixo coeficiente de determinação é através do agrupamento dessas plantas em "parcelas", ou seja, utilizando a média de plantas próximas, como pode ser observado na Figura 09, onde foram utilizados valores médios para cinco plantas com HAD próximo. Desta forma, o coeficiente de determinação aumentou de 0,25 para 0,66 para a variável produção (g) (Eigura 09b) e de 0,55 para 0,85, para a variável número de vagens por planta (Eigura 09a). Embora tenha ocorrido esse aumento no coeficiente de determinação, as curvas de regressão quando se utilizou do agrupamento em "parcelas", foram semelhantes às obtidas para todas plantas.

A variável de produção número de sementes por vagem (Eigura 10a-d) não mostrou correlação com nenhuma das variáveis independentes analisadas. YANG et alii (1991), estudando o patossistema soja - Phakopsora pachyrhizi, notaram que a variável número de sementes por vagem não era afetada pela doença e que a redução da produção era devida à redução no número de vagens. Essa variável, segundo BARROS (1980), é uma caracteristica inerente do cultivar, variando de 4 a 7 sementes por vagem para o cultivar Rosinha.

Analisando a Eigura 11a-d, pode-se observar que a variável peso de 100 sementes também não foi correlacionada com nenhuma das variáveis analisadas. Isso pode ser explicado, em parte, pelo fato da mancha angular causar lesōes superficiais nas vagens, năo afetando as sementes (LLANOS, 1957), contrariamente ao que ocorre com a antracnose do feijoeiro, onde o patógeno atravessa o tegumento das vagens, produzindo lesões deprimidas nos cotiledones (SCHWARTZ, 1991). 

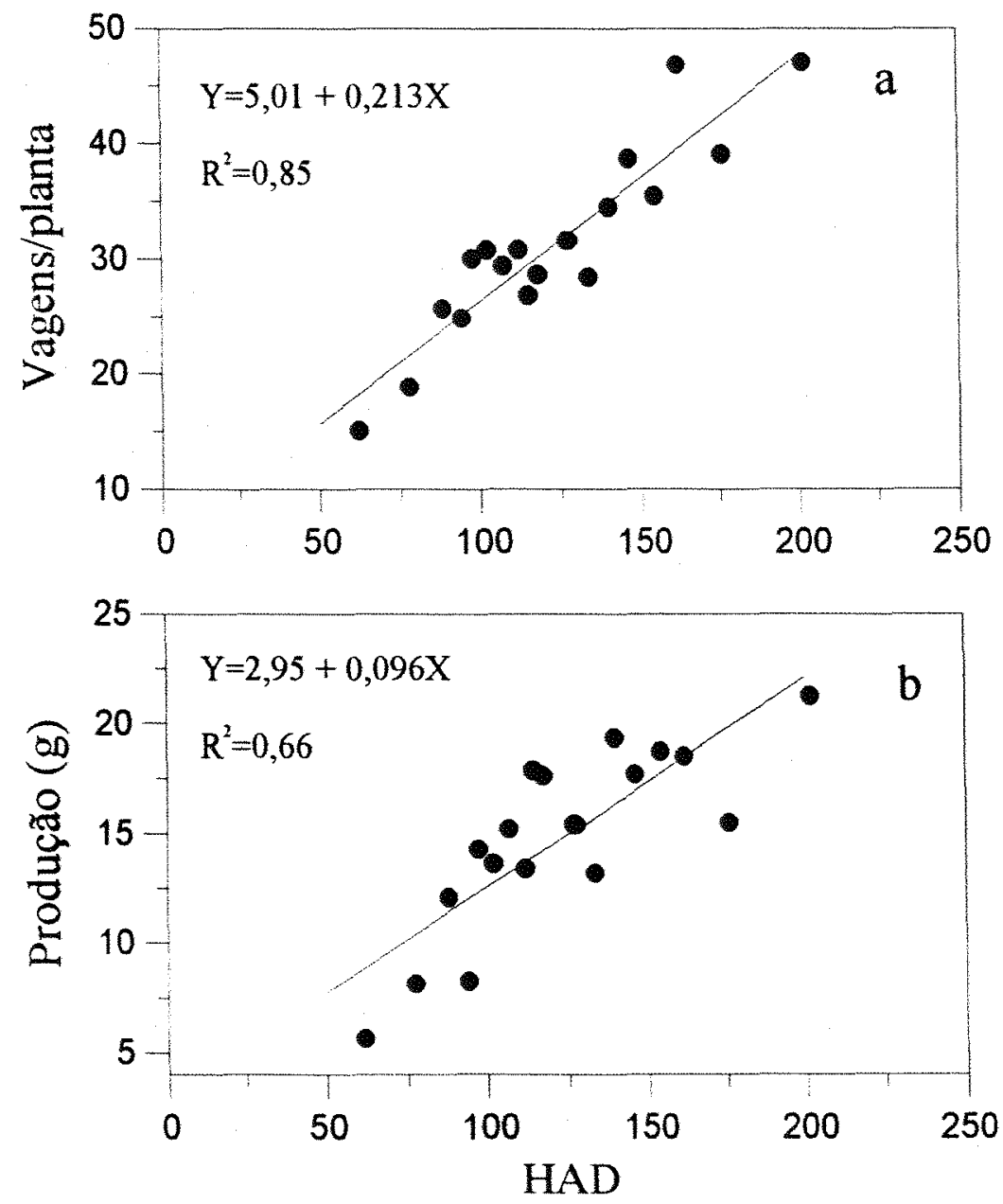

Eigura 09. Relaçăo entre HAD com número de vagens por planta (a) e produçăo em gramas (b) para o cultivar Rosinha (- média de cinco plantas). 

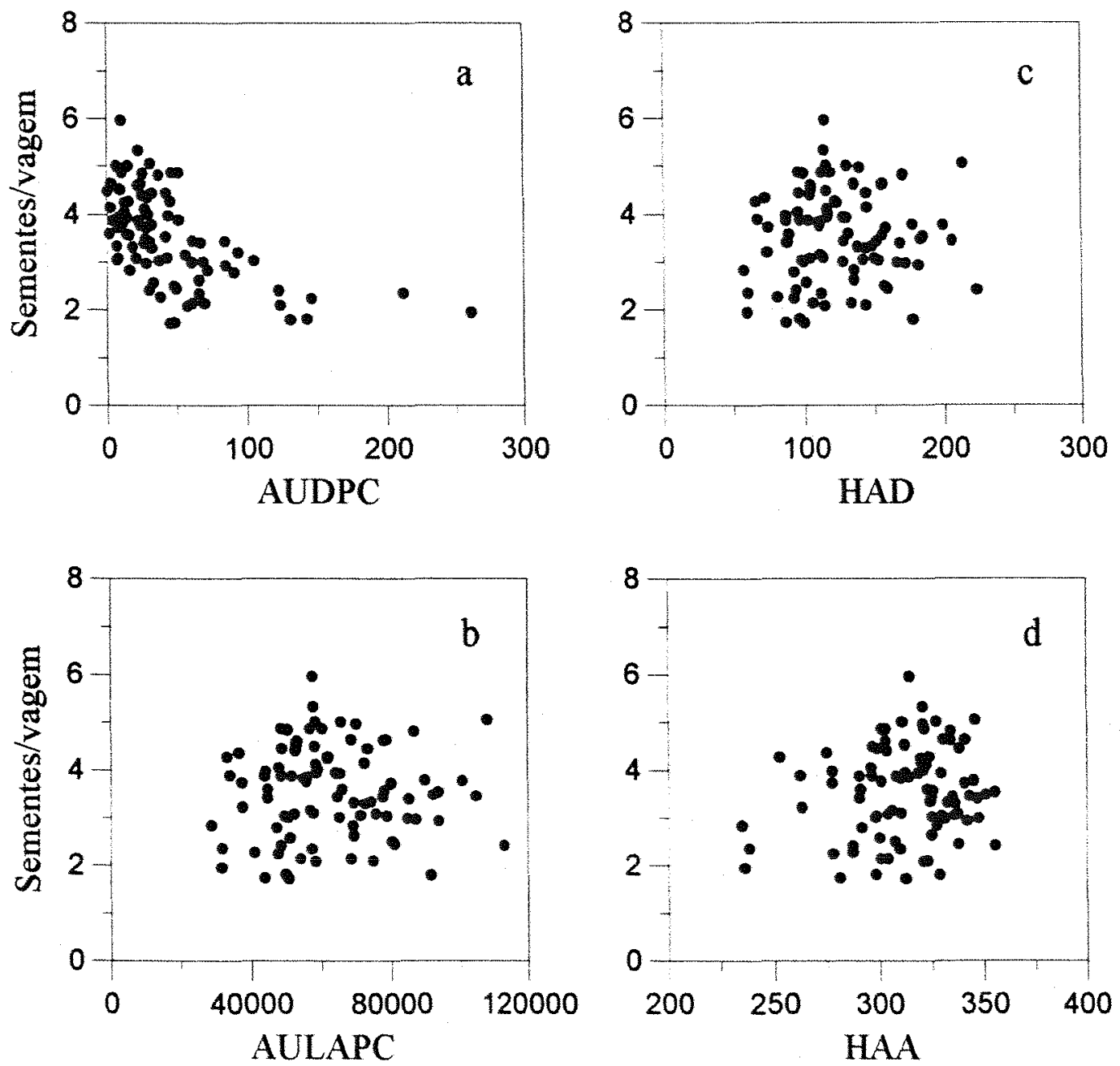

Eigura 10. Relaçăo entre as variáveis AUdPC (a), AULAPC (b), HAD (c) e HAA (d), e número de sementes por vagem para o cultivar Rosinha. 

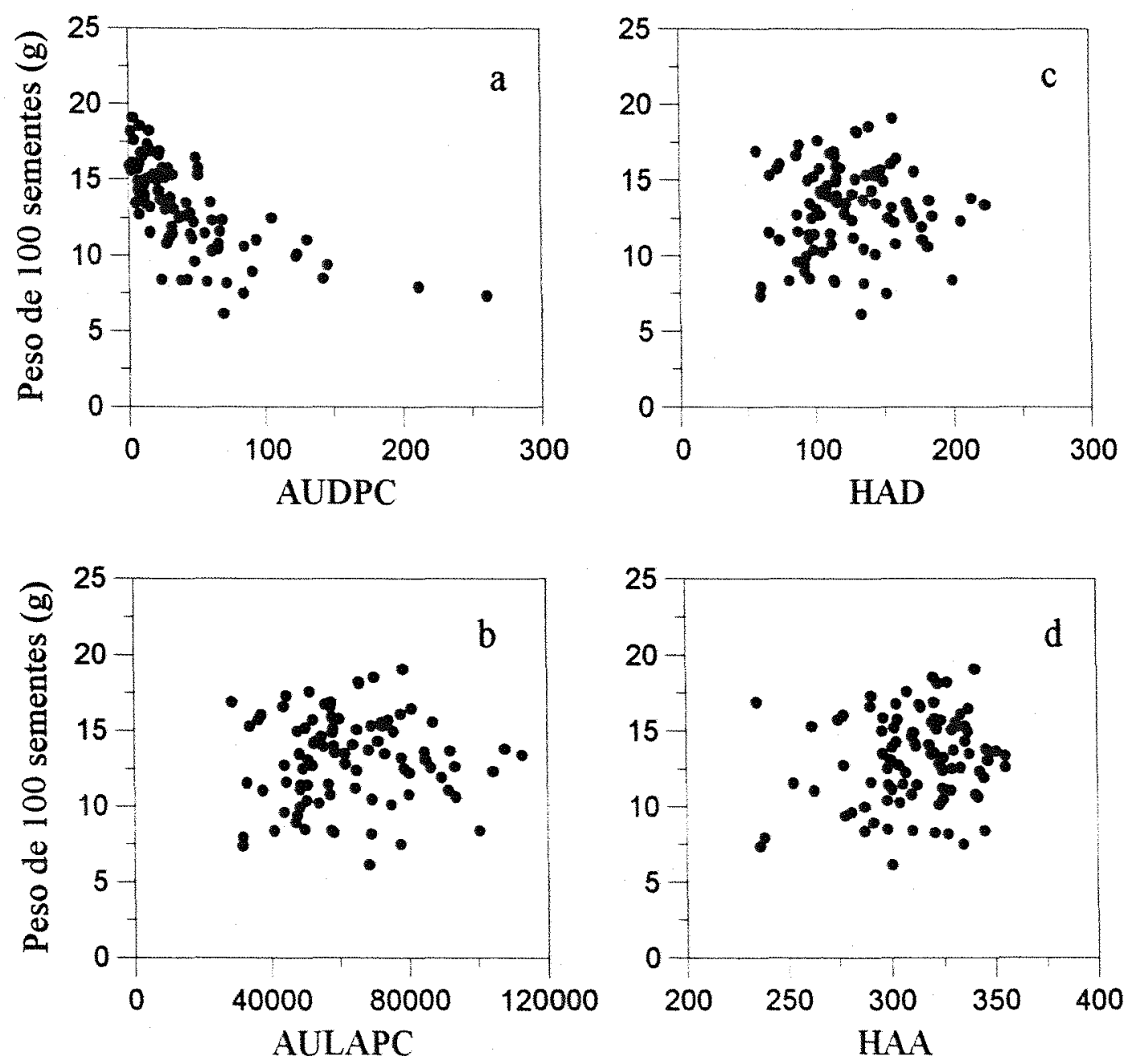

Eigura 11. Relaçào entre as variáveis AUDPC (a), AULAPC (b), $\operatorname{HAD}(\mathrm{c})$ e HAA (d), e peso de 100 sementes para o cultivar Rosinha. 
Como as variáveis de produção foram sempre relacionadas às variáveis derivadas da área foliar sadia do hospedeiro, é importante identificar se plantas que apresentavam maior quantidade de doença, também apresentavam pequena área foliar.

A influência da desfolha causada pela mancha angular na produção pode ser observada na Figura 12, onde foram plotadas a média do índice de área foliar sadio (LAI sadio) das 20 plantas mais doentes (AUDPC média de 106,15 unidades de área) e das 20 plantas menos doentes (AUDPC média de 6,53 unidades de área), nas respectivas datas de avaliação. Pode-se observar nessa figura que o LAI sadio das plantas sadias aumentou até a quinta avaliação 154 dias após o plantio). Na última avaliação, houve uma queda devido à desfolha natural que começou a ocorrer próxima a maturação. Já as plantas doentes, a partir da quarta avaliação (49 dias após o plantio), sofreram um processo de desfolha precoce em relação ao ciclo da cultura, devido à mancha angular, apresentando na última avaliação um LAI sadio muito inferior ao das plantas sadias. A produção média destes dois grupos de plantas foi, respectivamente, 20,5 e 8,7 gramas para as sadias e doentes.

MADEIRA et alii (1988), analisando o patossistema Ascochyta fabae - Vicia faba, observaram que parcelas com plantas infectadas mostraram uma queda mais rápida no índice de área foliar do que as plantas sadias, sugerindo a senescência precoce. As diferenças de produçăo nesse caso foram devidas à diferença no peso de sementes, uma vez que a infeç̧ão tardia não afetou o número de vagens ou o número de sementes por vagem quando comparados com plantas sadias. 


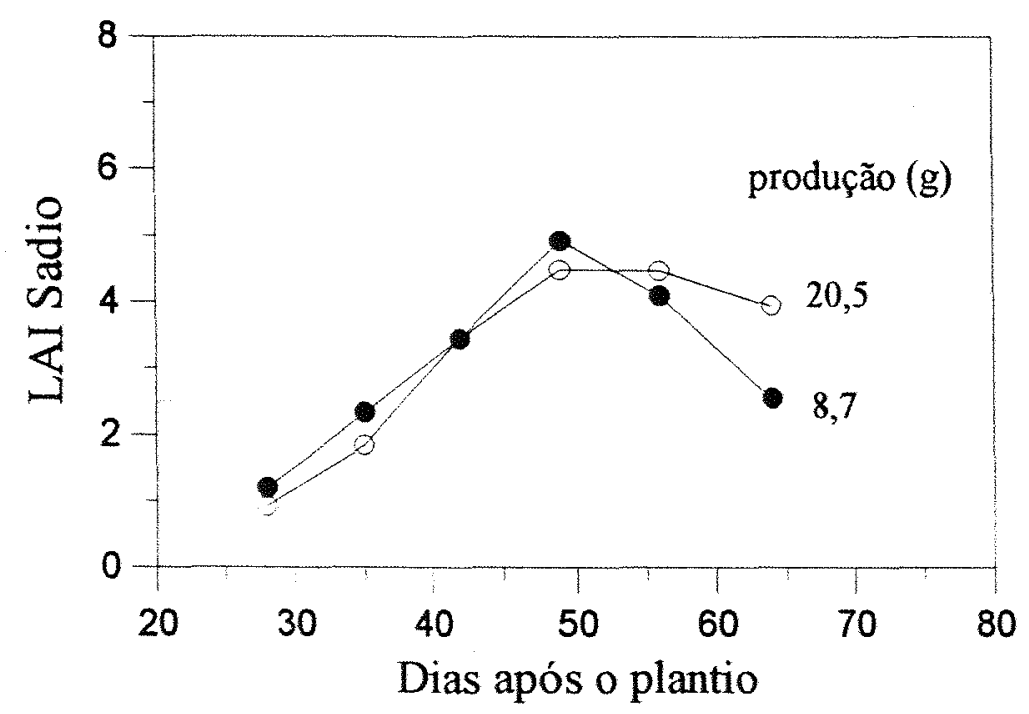

Figura 12. Curvas de progresso do índice de área foliar sadia para plantas sadias 10 - média de 20 plantas) e doentes (• - média de 20 plantas) e suas respectivas produções médias (cultivar Rosinha).

MCEWEN (1972), estudando o efeito da desfolha artificial em plantas de Vicia faba, observou que quando as folhas eram removidas após o florescimento, ocorria uma competição grande pelas vagens por suprimentos de carboidratos e nitrogênio. As zonas remanescentes eram responsáveis pela produção de carboidrato necessário para o enchimento das vagens. Esse autor observou ainda que a desfolha parcial causava danos na produção através da redução no número de vagens, não afetando o tamanho das sementes ou o numero de sementes por vagem.

A desfolha causada pela mancha angular se iniciou a partir da quarta avaliação, quando o Eeijoeiro se 
encontrava no estádio $R_{7}$ (início da formação das vagens). Nas avaliações seguintes, estádio $R_{8}$ (enchimento de vagens), o índice de área foliar das plantas doentes era menor quando comparado com as plantas sadias, 0 que comprometeu a produção, através do enchimento das vagens, uma vez que essas chegavam a ser formadas, mas permaneciam vazias. Esse fato foi observado para as parcelas que receberam as maiores concentrações de inóculo ( $K$, L e $M$ da Tabela 02), onde devido a desfolha precoce, ocorreu um grande número de vagens vazias. MORA-BRENES (1983) observou esse mesmo fato quando estudou os danos causados por diferentes concentrações de inóculo inicial de mancha angular nas variedades de feijão Cauca 27 a e Caraota 260, no CIAT (Centro Internacional de Agricultura Tropical) na Colômbia em 1982 .

A Figura 13 ilustra o efeito da desfolha nas parcelas que receberam diferentes concentrações de inóculo. Os gráficos da Eigura $13 a, c$ representam as parcelas que receberam o inóculo menos concentrado, e aqueles da Figura $13 \mathrm{~b}, \mathrm{~d}$, as que receberam o inóculo mais concentrado. Podese observar que quanto maior a concentração do inóculo, maior o efeito da desfolha nas parcelas, ou seja menor indice de área foliar final.

Na Tabela 03 pode-se observar as produções médias das seis plantas marcadas de cada parcela. As plantas das parcelas que receberam as maiores concentrações de inóculo apresentaram sempre as menores produções devido a desfolha precoce ocasionada pela doença. 

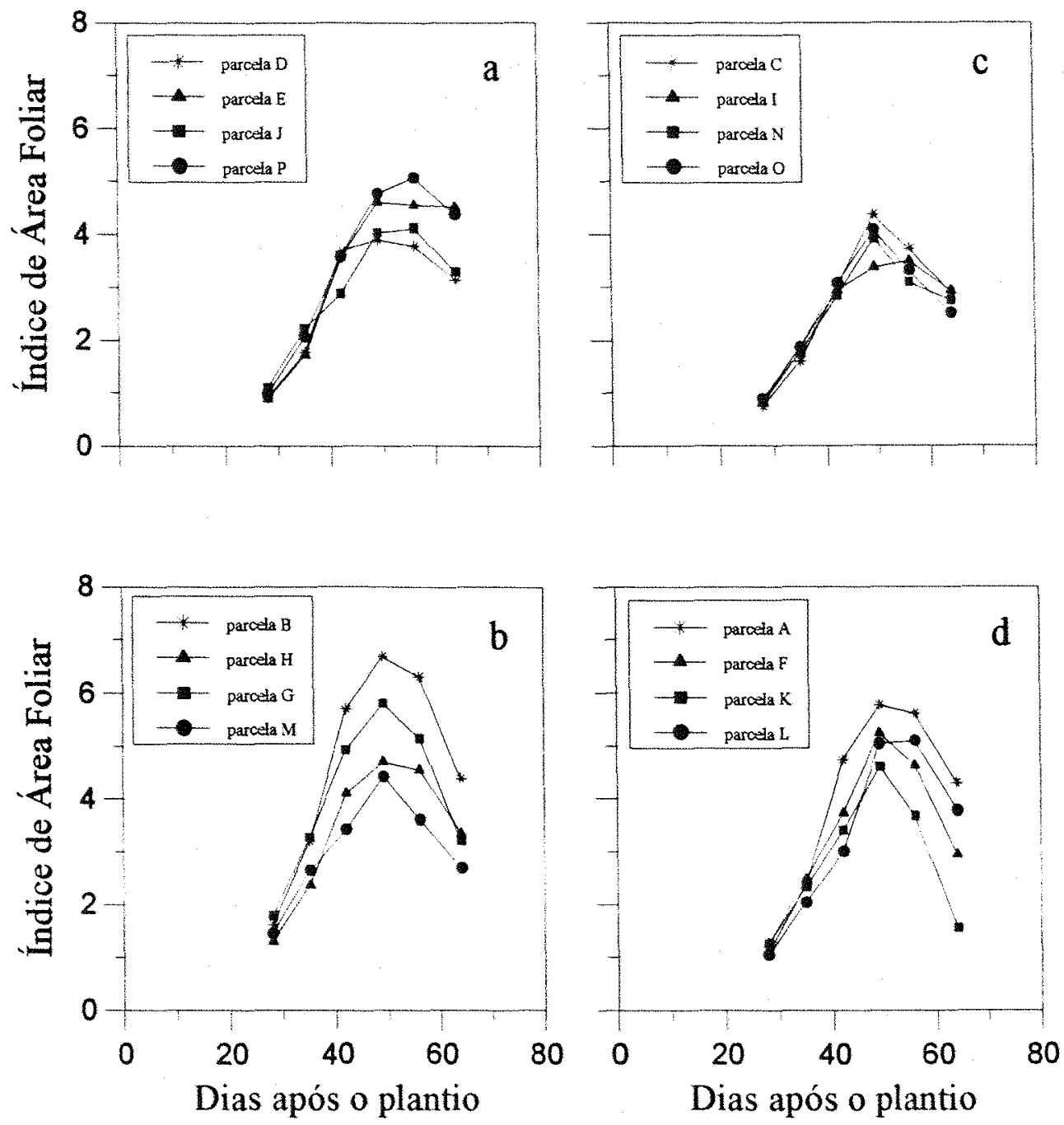

Eigura 13. Curvas de progresso do índice de área foliar nas parcelas do cultivar Rosinha com diferentes concentrações de inóculo. Cada curva representa a média das seis plantas de cada parcela. As concentraçōes do inóculo crescem no sentido a, $c, b$ e d. 
Tabela 03. Produções médias das seis plantas marcadas em cada parcela do ensaio com o cultivar Rosinha.

\begin{tabular}{cc|cc}
\hline Parcela & $\begin{array}{c}\text { Produção } \\
\text { (gramas/planta) }\end{array}$ & Parcela & $\begin{array}{c}\text { Produção } \\
\text { (gramas/planta) }\end{array}$ \\
\hline A & 14,99 & I & 15,67 \\
B & 20,71 & J & 19,25 \\
C & 15,26 & K & 6,36 \\
D & 16,76 & L & 8,32 \\
E & 21,26 & M & 5,79 \\
E & 16,35 & N & 9,18 \\
G & 18,23 & O & 8,83 \\
H & 15,93 & P & 23,33 \\
\hline
\end{tabular}

\subsection{Avaliação de danos causados pela mancha angular no cultivar Carioca}

As mesmas análises realizadas para o cultivar Rosinha foram feitas para o cultivar Carioca. Através da Eigura 14 pode ser observada a distribuição da severidade da doença (em AUDPC) alcançada neste ensaio. O níveis máximo de AUDPC (113 unidades de área) foi inferior quando comparado com o ensaio com o cultivar Rosinha. Isso pode ser explicado, em parte, pelo menor número de inoculações realizadas neste ensaio. Pode-se observar também por esta figura, que poucas plantas se mantiveram sadias, embora a parcela testemunha tenha sido pulverizada semanalmente com o Eungicida benomyl. 


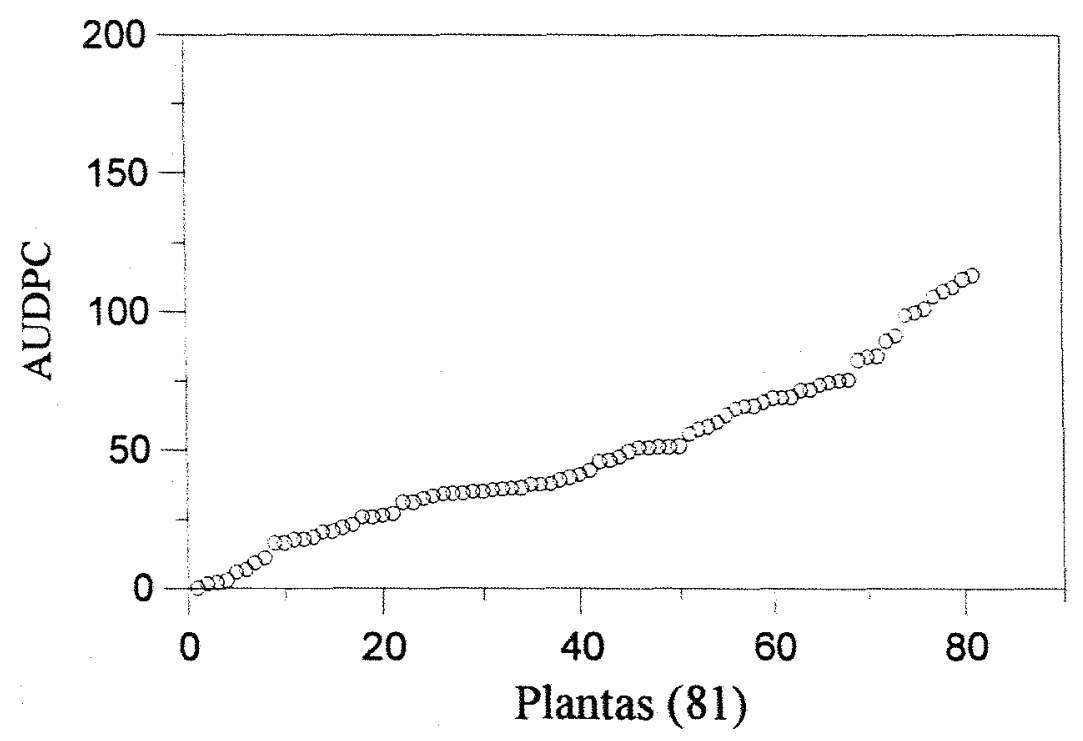

Figura 14. Distribuição da severidade (em AUDPC) obtida nas plantas do cultivar Carioca marcadas no campo.

Nas Figuras 15 e 16 estão representados o progresso da área foliar e da severidade de mancha angular em relação às variáveis produção $(g)$ e número de vagens por planta, respectivamente. Os sintomas se iniciaram a partir dos 43 dias após o plantio, aumentando até a última avaliação, onde atingiu um máximo de $15 \%$ de severidade. A área foliar aumentou até os 52 dias após o plantio, atingindo um máximo de $3000 \mathrm{~cm}^{2}$. Na última avaliação, apresentava-se muito inferior devido, em parte, ao processo de senescencia natural, e também à desfolha causada pela mancha angular.

Nào foi encontrada correlaçăo entre severidade de doença (em AUDPC) e produção, como pode ser observado nas 
Eiguras 17a e 18a, para produção (gramas) e número de vagens por planta, respectivamente. No entanto, foram observadas correlações com as variáveis de área foliar sadia, para ambas as variáveis de produção (Eigura 17c-d e 18c-d), sendo os coeficientes de determinação encontrados neste ensaio superiores quando comparados com os coeficientes encontrados no ensaio com o cultivar Rosinha.

Isso pode ter ocorrido em função da menor intensidade de doença alcançada neste ensaio, que resultou numa menor desfolha, ocasionando desta forma uma menor variabilidade no tamanho das plantas, emoora poucas plantas tenham ficado sadias até o final do ciclo da cultura.

A menor produção alcançada neste ensaio, quando comparada corn o ensaio com o cultivar Rosinha, pode ser explicada pela menor área foliar alcançada. Segundo PORTES (1988) quanto maior a área foliar do feijoeiro, maior interceptação de luz e conseqüentemente maior produtividade de matéria seca e de grãos. As variáveis de área foliar AULAPC e HAD atingiram um máximo de 80.000 e 160 unidades de área, respectivamente, enquanto que para o cultivar Rosinha, as mesmas variáveis atingiram valores de 120.000 e 210 unidades de área, respectivamente.

Os coeficientes de determinação, podem ser melhorados, da mesma maneira utilizada anteriormente para o cultivar Rosinha, ou seja, agrupando-se as plantas em "parcelas". Desta forma, os coeficientes de determinação para as variáveis produção $(g)$ e número de sementes por vagem, e HAD aumentaram de 0,57 e 0,67 para 0,84 e 0,89, respectivamente, como pode ser observado na Eigura 19. 

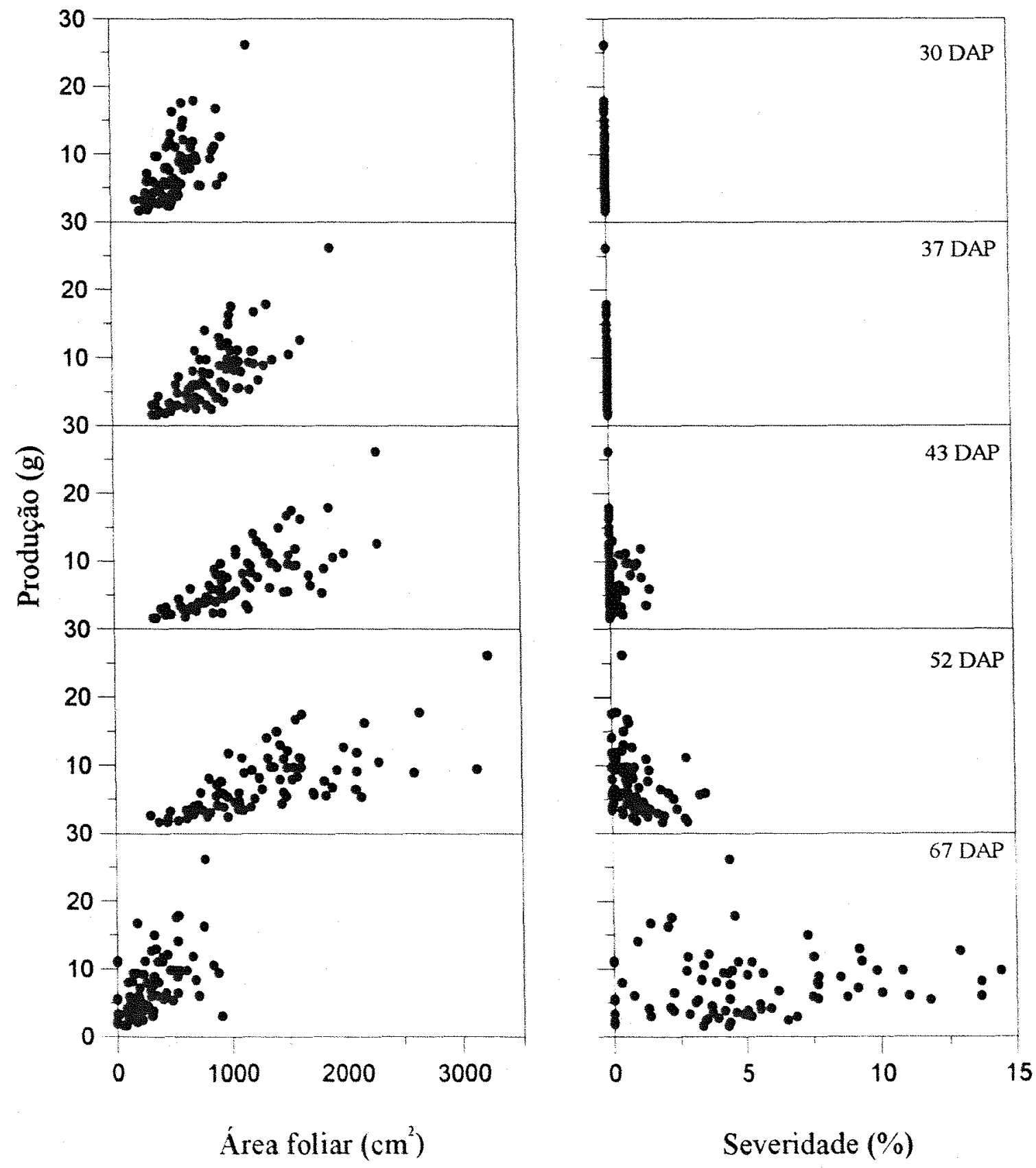

Eigura 15. Relação entre área foliar do feijoeiro $\left(\mathrm{cm}^{2}\right)$ e severidade (o $)$ com a produçăo $(g)$, em cinco avaliaçoes (cultivar carioca). 

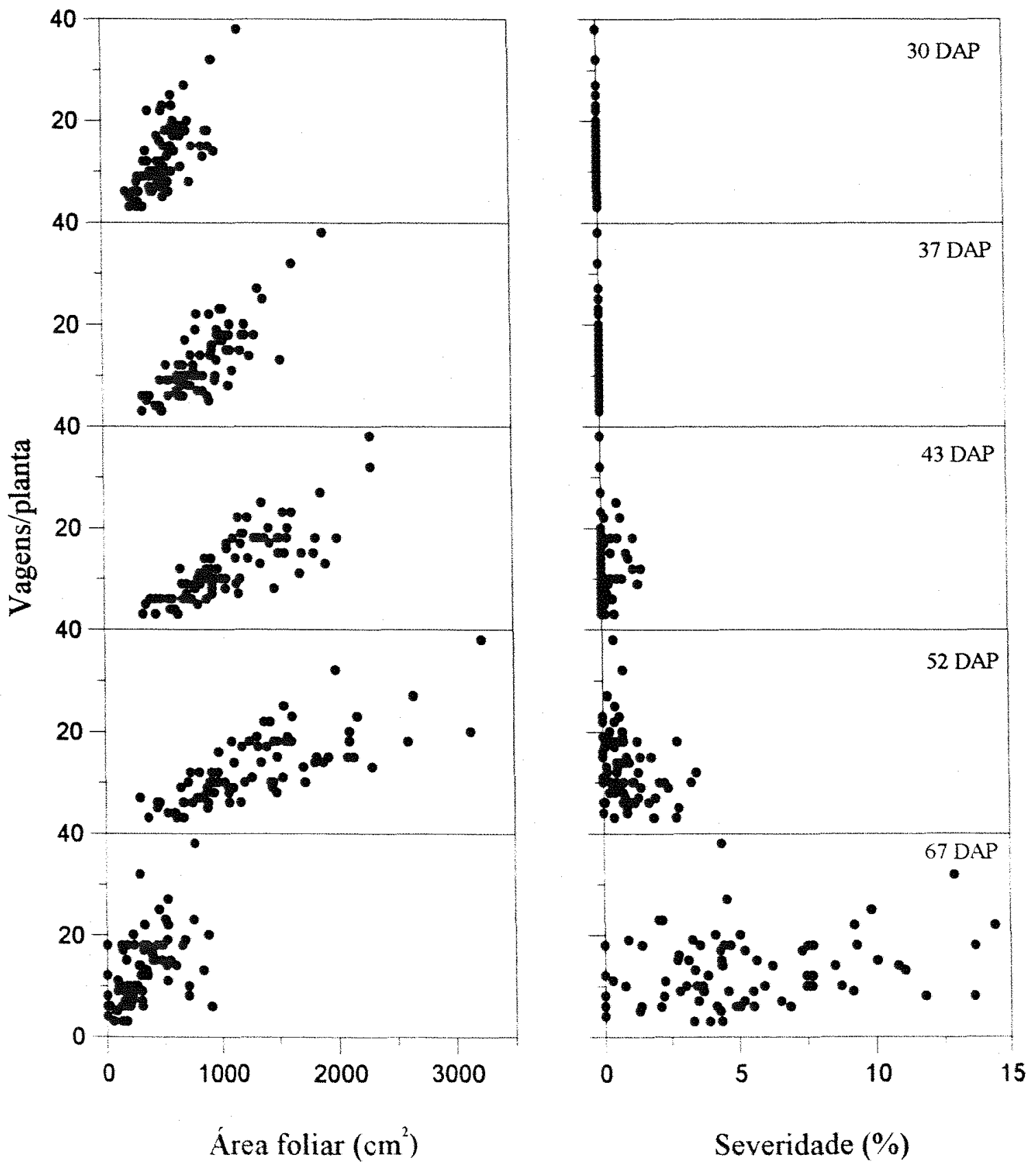

Figura 16. Relaçăo entre área foliar do feijoeiro $\left(\mathrm{cm}^{2}\right)$ e severidade $\left(\frac{0}{\partial}\right)$ com o número de vagens por planta, em cinco avaliaçoes (cultivar carioca). 

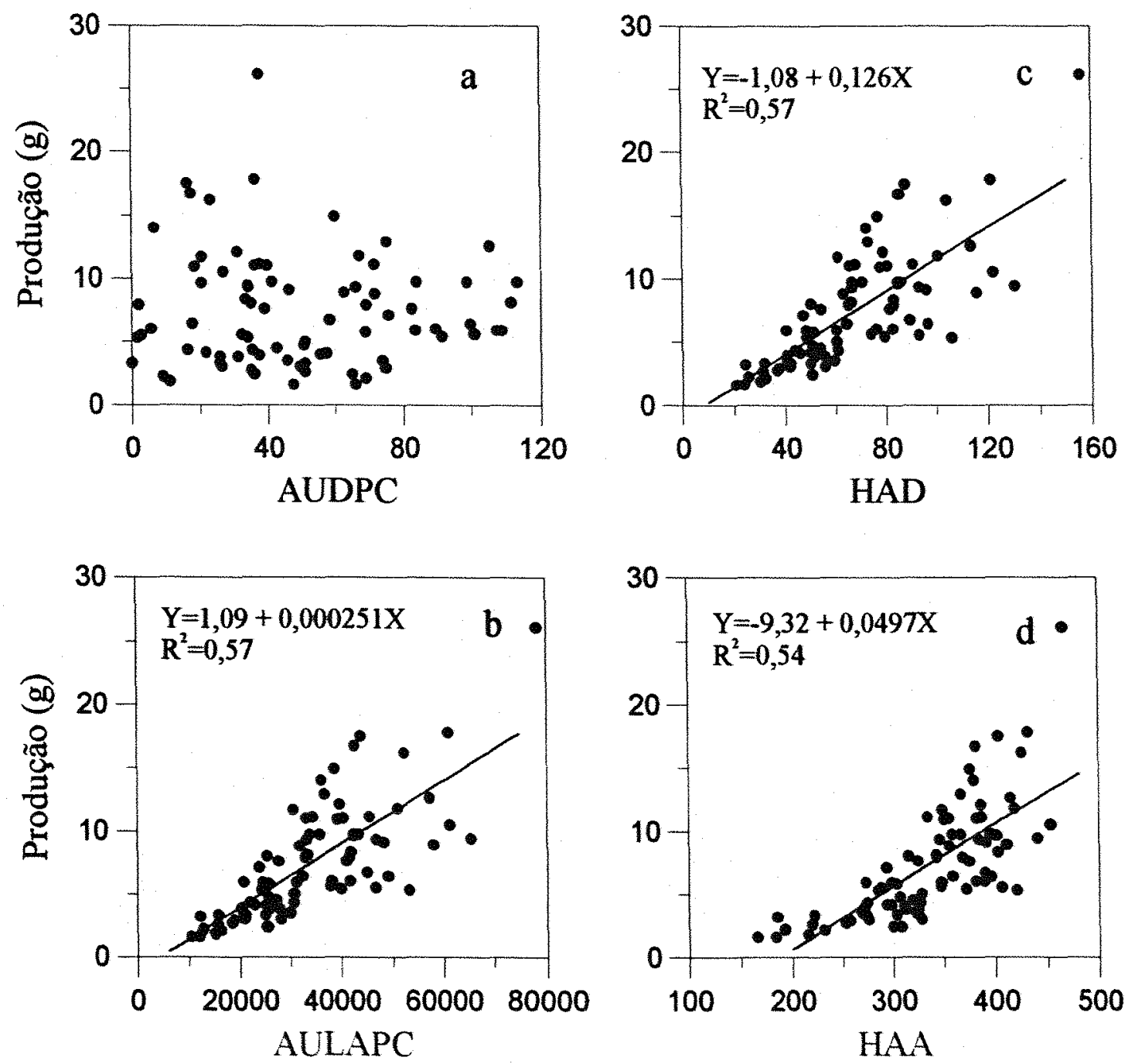

Figura 17. Relação entre as variáveis AUDPC (a), AULAPC (b), HAD (c) e HAA (d), e produção (gramas por planta) para o cultivar Carioca. 

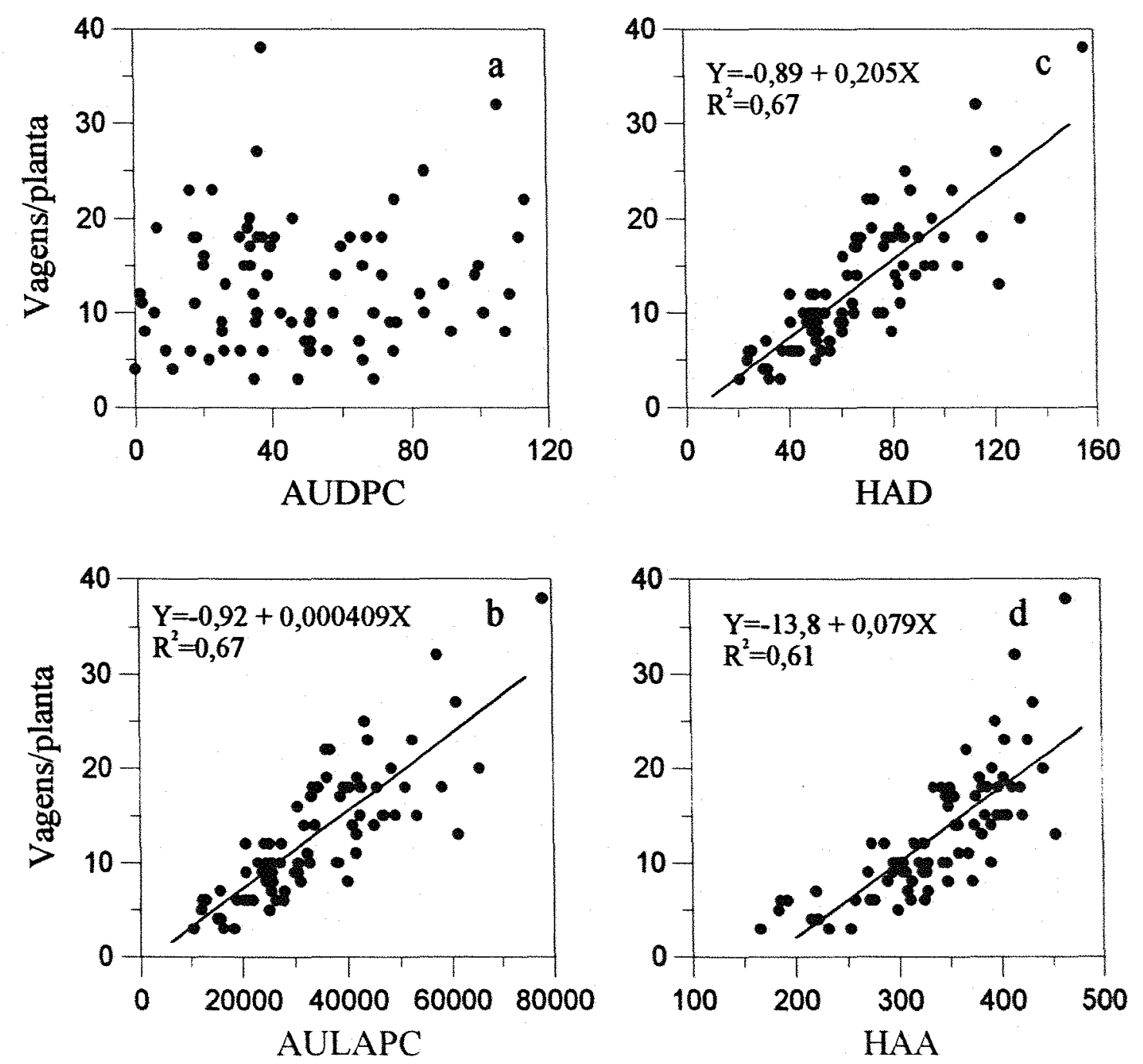

Figura 18. Relação entre as variáveis AUDPC (a), AULAPC (b), HAD (c) e HAA (d), e número de vagens por planta para o cultivar Carioca. 

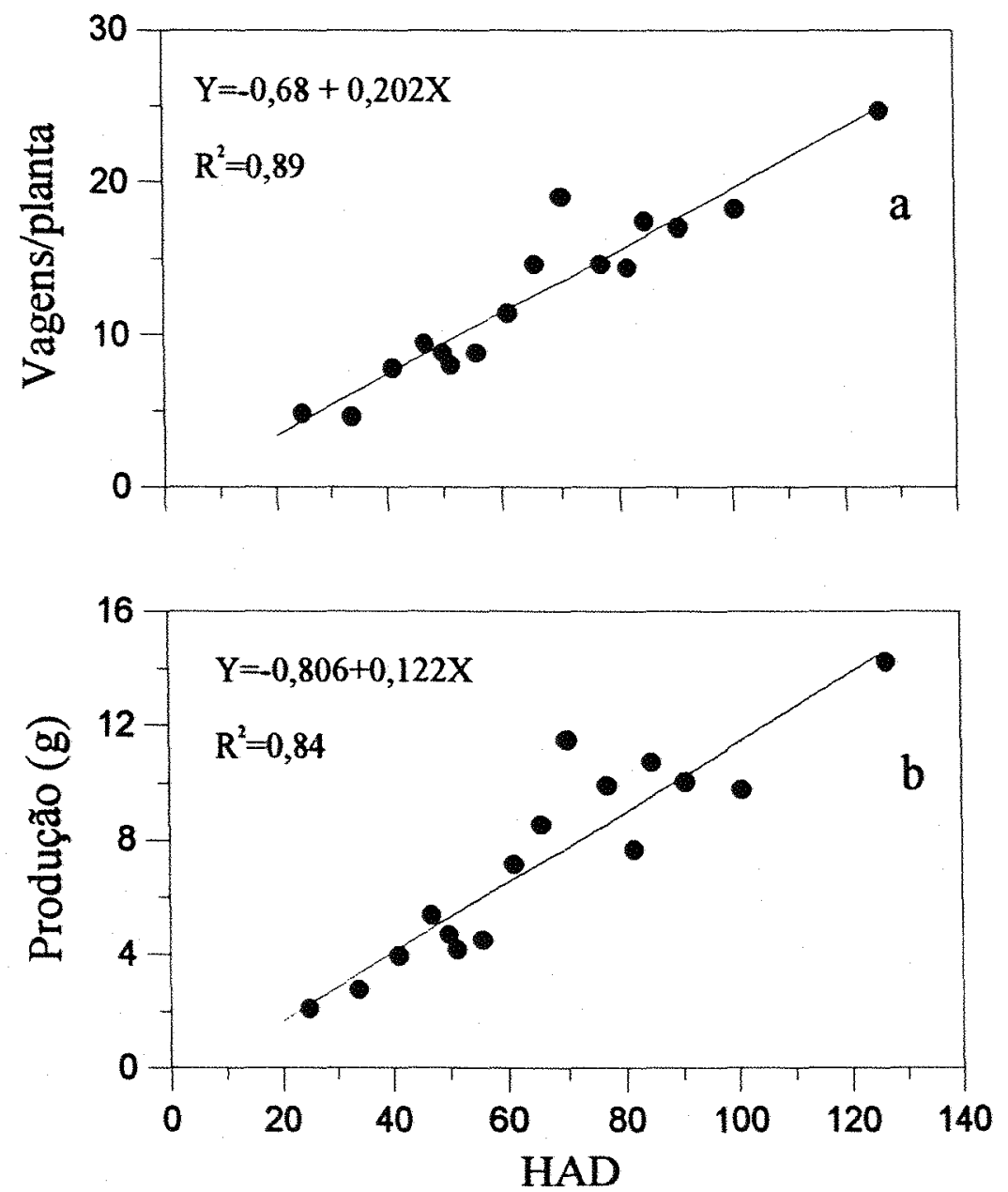

Eigura 19. Relação entre HAD com número de vagens por planta (a) e produção em gramas (b) para o cultivar Carioca (- - média de cinco plantas). 
As variáveis de produção, número de sementes por vagem e peso de 100 sementes, não apresentaram correlação com doença (AUDPC), nem com as variáveis de área foliar, mostrando novamente que o número de sementes por vagem é uma caracteristica inerente do cultivar e o peso de 100 sementes não é afetado pela doença (Apêndices 02 e 03).

Para se verificar o efeito da desfolha causada pela mancha angular, foram plotados os índices de área foliar sadio (LAI sadio) para as 20 plantas mais sadias (AUDPC média de 14,42 unidades de área) e para as 20 plantas mais doentes (AUDPC média de 89,38 unidades de área), e verificou-se que as plantas doentes mantiveram um LAI sadio superior durante todo o ciclo da cultura e apresentaram um mesmo LAI sadio final quando comparadas com as plantas sadias (Apêndice 04). Esse LAI sadio superior das plantas doentes pode ser explicado pela variação inerente entre as plantas, e o mesmo LAI sadio final ocorreu pelo fato da cultura se encontrar em estado avançado de maturação na última avaliação.

Quando se separou as parcelas por concentração de inóculo, foi observado o mesmo fato, parcelas com maiores e menores concentrações de inóculo inicial apresentam um mesmo indice de área foliar final (Apêndice 05). As produções médias das seis plantas de cada parcela para o cultivar Carioca se encontram no Apêndice 06 . 


\subsection{Manejo da mancha angular do feijoeiro baseado na área foliar sadia das plantas}

Uma possivel maneira de se utilizar essa nova abordagem de avaliação de danos através das variáveis de área foliar sadia em um sistema de manejo da mancha angular está ilustrada nas Figuras 20 e 21. Como para um sistema de manejo de doença não é viável a utilização de variáveis integrais, pois somente no final da epidemia seria possível descobrir quando deveria ter sido utilizada uma medida de controle, há a necessidade de se utilizar variáveis instantâneas como por exemplo o índice de área foliar (LAI) .

Desta forma, utilizando-se de plantas sadias, obtevese curvas de resposta às variáveis de produção (produção em gramas e número de vagens por plantal para as diferentes datas de avaliação. No lado esquerdo das Figuras 20 e 21 foram utilizadas todas plantas individuais, e no lado direito, o agrupamento em "parcelas", conforme já realizado anteriormente para a variável HAD. Pode-se observar que o coeficiente de determinação é bastante alto até a quarta avaliação para ambos parâmetros de produção, sendo sempre superior a 0,85. Desta forma, através de curvas padrões para os diferentes cultivares, seria possivel estimar a produção final, através da análise do índice de área foliar instantâneo da cultura, e caso a produção estimada estivesse baixa, poderia-se entrar com a medida de controle recomendada. As Eiguras para o cultivar Rosinha encontramse nos Apêndices 07 e 08 .

- inovador seria substituir área doente por área foliar total e dano por produção. Teoricamente, uma produção ideal alcançada com determinada área foliar, deve 
ser esperada num nível de manejo adequado e outras variáveis, além da mancha angular, podem ser consideradas.

Essa abordagem de se correlacionar variáveis de área foliar com produção já foi utilizada com sucesso por NUNES (1994) no patossistema feijoeiro - Colletotrichum Iindemuthianum, e vem sendo utilizada para essa mesma cultura com ferrugem (Uromyces appendiculatus) por IAMAUTI (1995) e mancha angular (Phaeoisariopsis griseola) em Londrina/Paraná, por CARNEIRO ${ }^{2}$. Em nenhum dos casos anteriores foi encontrada correlação entre severidade de doença e produção.

Para a implantação de um sistema de manejo utilizando como base curvas de resposta padrão, seriam necessários mais estudos, para verificar se estas curvas de resposta se repetem para diferentes locais e épocas de cultivo, gerando desta forma um sistema transportável, capaz de produzir recomendações precisas e acuradas a nível de propriedade.

LOPES et alii (1994) e BERGAMIN FILHO et alii (1995) discutem essa abordagem e propõem o estabelecimento de um sistema de manejo através da utilização da variável explanatória absorção da área foliar sadia (HAA) e de um segundo componente, a parcela controle, livre de doença. Os ensaios de campo seriam utilizados para se estabelecer uma relação entre diminuição da área foliar sadia e a respectiva diminuição da produção, mesmo considerando um patossistema múltiplo. A partir desta relação, e dispondo de informações sobre a eficiência das possiveis medidas de controle e sobre os custos e beneficios envolvidos, poderia ser definido um limiar de dano econômico expresso em unidades de HAA $\left(\mathrm{MJm}^{-2}\right)$. Segundo esses autores, a mesma

${ }^{2}$ CARNEIRO, S.M.T.P.G. (IAPAR/Londrina). Comunicação pessoal. 
abordagem poderia ser utilizada para outras variáveis de área foliar sadia, como HAD e LAI. 


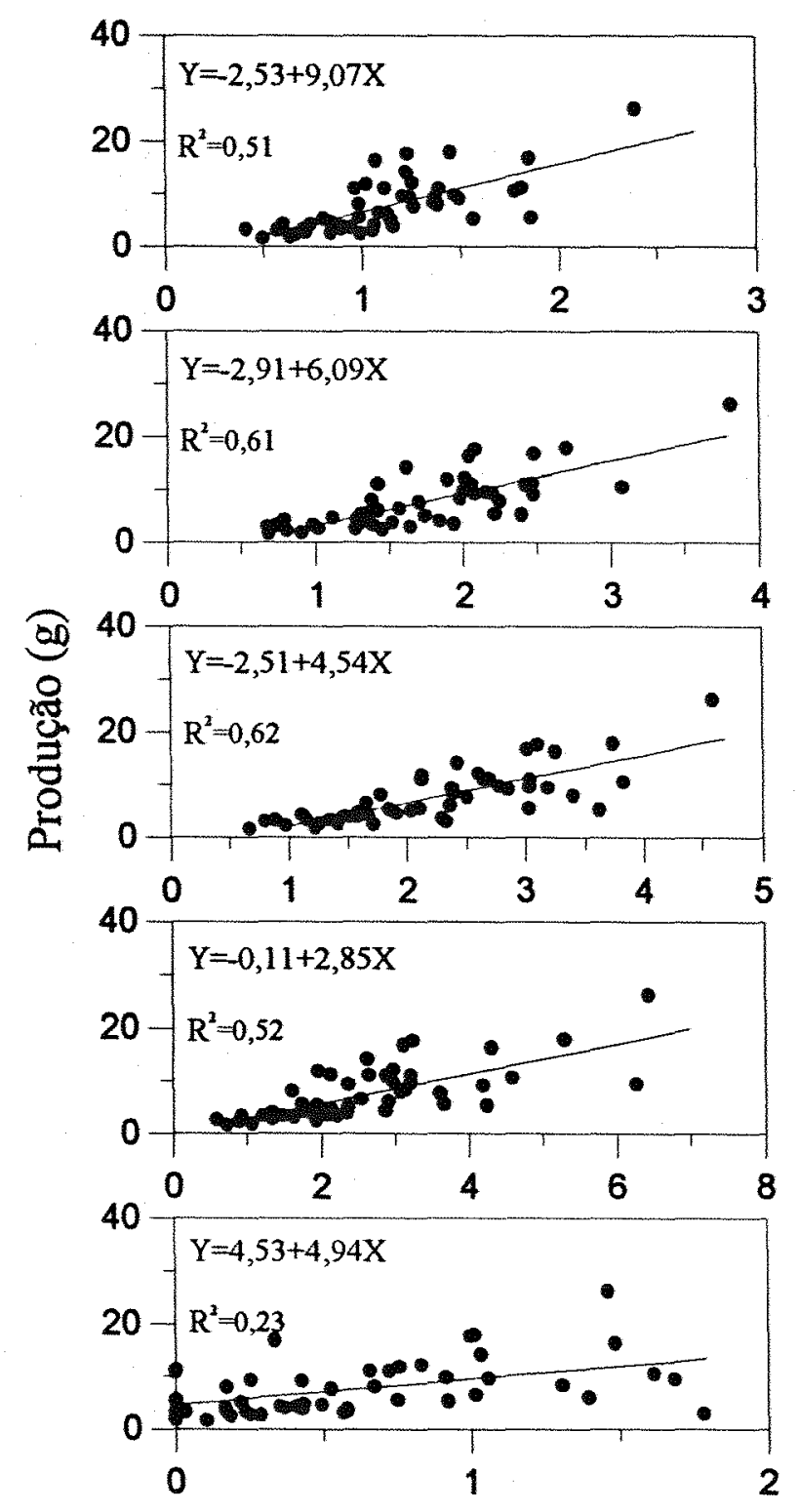

LAI Sadio
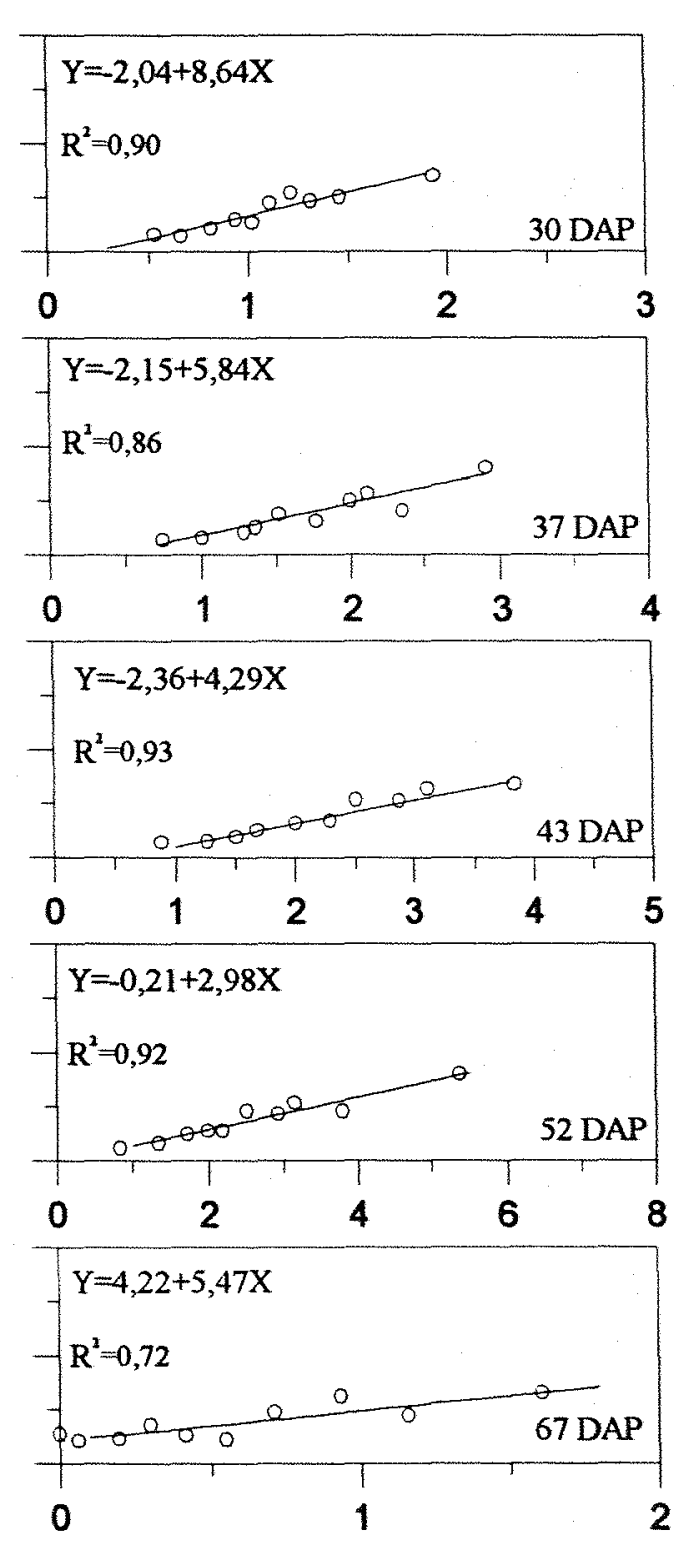

LAI Sadio

Eigura 20. Relação entre índice de área foliar sadia e produção (g) para as plantas sadias do cultivar Carioca, nas cinco datas de avaliação - - todas plantas, o - média de cinco plantas). 


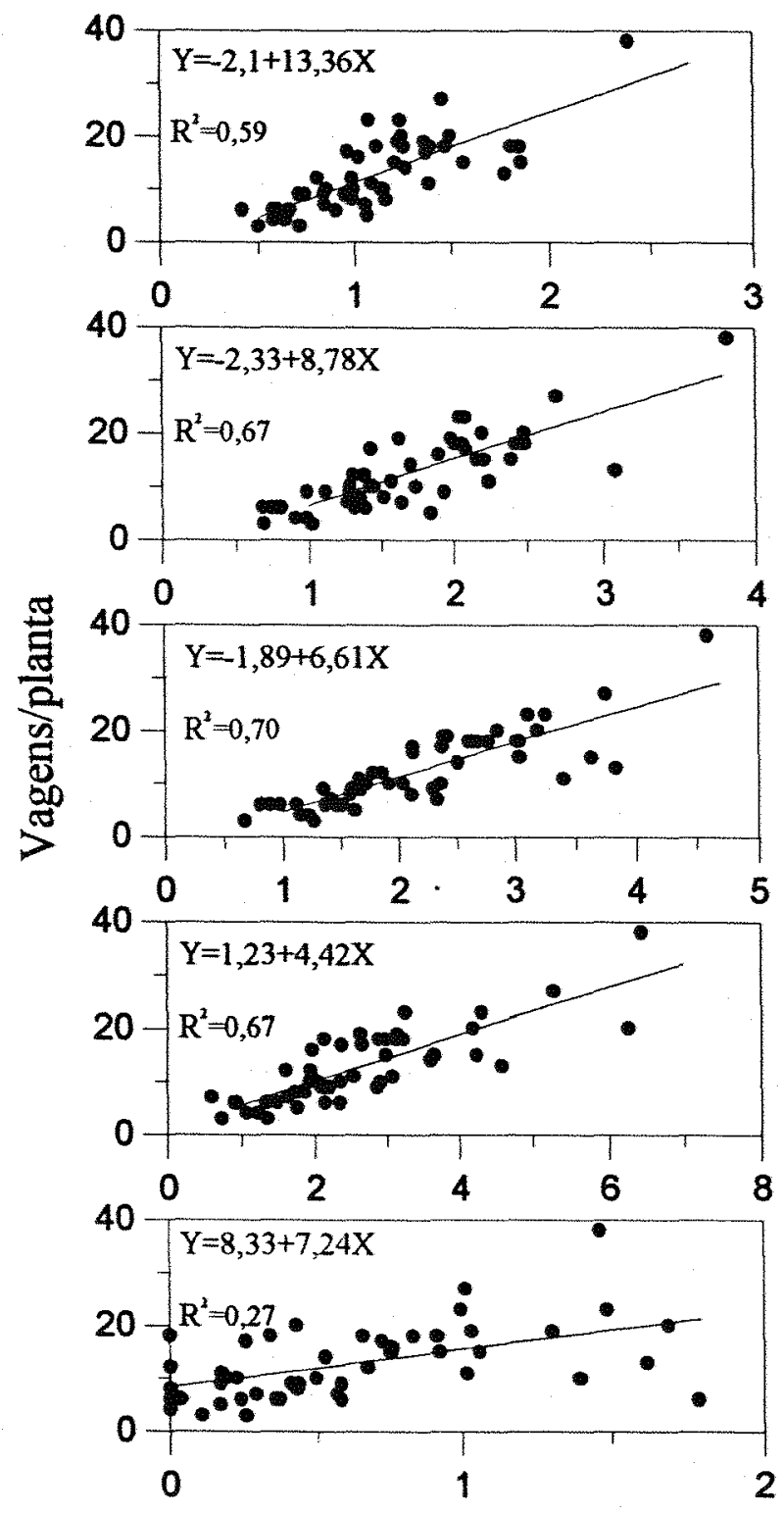

LAI Sadio
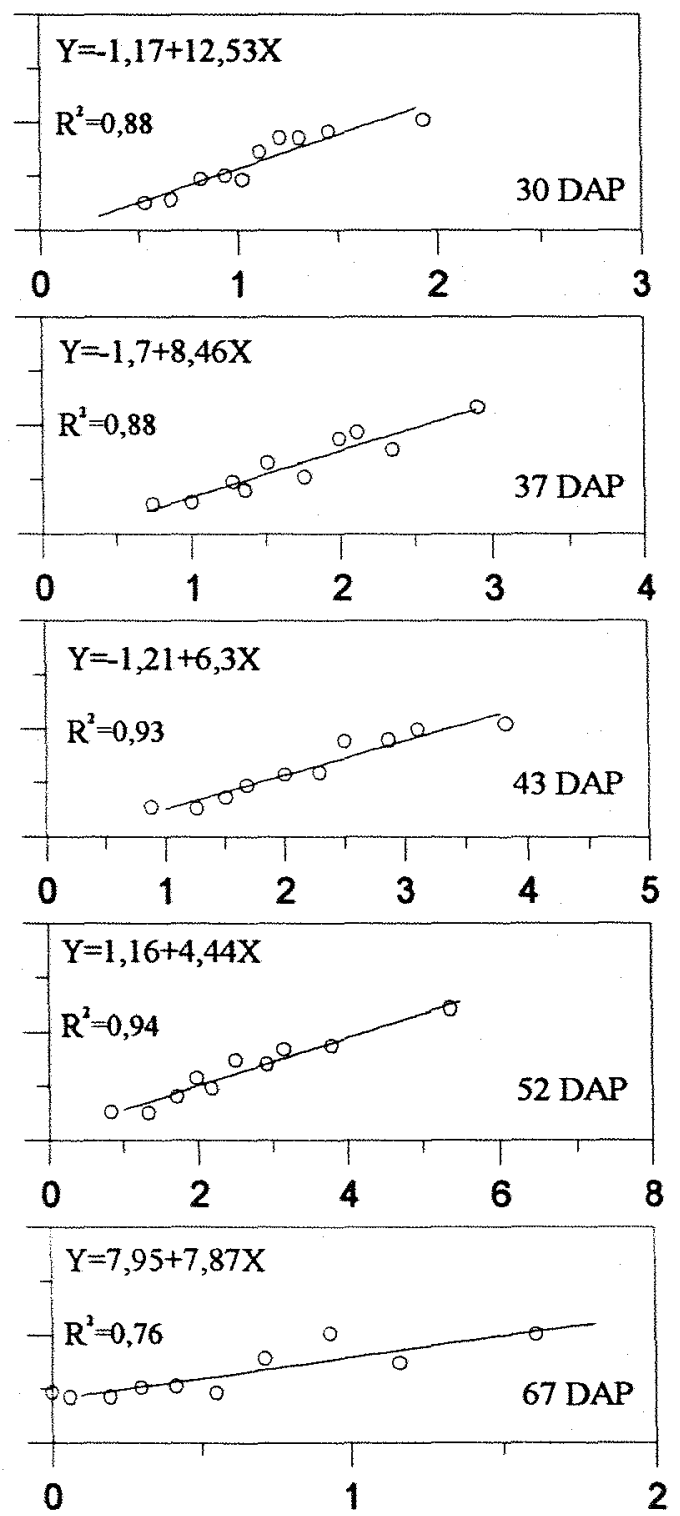

LAI Sadio

Eigura 21. Relação entre indice de área foliar sadia e número de vagens por planta para as plantas sadias do cultivar Carioca, nas cinco datas de avaliação (• - todas plantas, o - média de cinco plantas). 


\section{CONCLUSÕES}

1. A função de dano, definida como relação entre injúria e dano, não pôde ser estabelecida para o patossistema Phaeoisariopsis griseola - feijoeiro, pois a variável injúria (expressa em severidade de doença) não explicou a redução de produção.

2. A produção do feijoeiro apresentou melhor correlação com as variáveis de área foliar sadia lárea sob a curva de progresso da área foliar - AULAPC; absorção da área foliar sadia - HAA e duração da área foliar sadia HAD).

3. A quantificação da severidade da mancha angular deve incorporar o efeito da desfolha para uma estimativa mais acurada da intensidade da doença.

4. Este trabalho fornece dados para um futuro estudo de implementação de um sistema de manejo integrado desta doença, baseado nas variáveis de área foliar sadia. 


\section{REFERÊNCIAS BIBLIOGRÁFICAS}

BANNO, K. Oferta e comercialização de feijão no Brasil. In: SEMINÁRIO SOBRE PRAGAS, DOENÇAS E PLANTAS DANINHAS DO EEIJOEIRO, 5. Piracicaba, 1994. Anais. Piracicaba, EEALQ, 1994. p.27-44.

BARROS, D.; CADORNA, C.; CARDEÑOSA, R.; SKILES, R.L. The control of angular leaf spot of bean in Colombia. plant Protection Bulletin, Roma, 6: 97-101, 1958.

BARROS, L.G. Caracterização de alguns dos cultivares de feijão (Phaseolus vulgaris L.) indicados para o Brasil. Viçosa, 1983. 105p. (M. S. - Universidade Federal de Viçosa).

BERGAMIN EILHO, A. Avaliação de danos e perdas. In: BERGAMIN EILHO, A.; KIMATI, H.; AMORIM, L., ed. Manual de fitopatologia. $\quad 3^{a}$ ed. São Paulo, Ceres, 1995. v. 1. p. 297-318.

BERGAMIN EILHO, A.; LOPES, D.B.; AMORIM, L.; GODOY, C.V.; BERGER, R.D. Avaliação de danos causados por doenças de plantas. In: LUZ, W.C., ed. Revisão anual de patologia de plantas, Passo Eundo, 3: 133-84, 1995. 
CAMPBELL, C.L. \& MADDEN, L.V. Introduction to plant disease epidemiology. New York, John Wiley \& Sons, 1990. 532p.

CAMPOS, J.A. \& ZAK, L.E. Estudio de algunas caracteristicas de Isariopsis griseola Sacc., agente causal de la mancha angular del frijol. Agrociência, Chapingo, 39:41-8, 1980.

CARDONA-ALVAREZ, C. Herencia de la resistencia a la mancha angular en frijol. Agricultura Tropical, Bogotá, $18: 330-1,1962$.

CARDONA-ALVAREZ, C. \& WALKER, J.C. Angular leaf spot of bean. Phytopathology, St. Paul, 46: 610-5, 1956.

DALLA PRIA, M. \& BERGAMIN FILHO, A. Avaliação de diferentes meios de cultura na esporulação de Colletotrichum Iindemuthianum, Isariopsis griseola e Alternaria sp. In: CONGRESSO PAULISTA DE FITOPATOLOGIA, 17. Piracicaba, 1995. (Resumo) Summa Phytopathologica, Jaguariúna $21(1)$. (no prelo)

FANCELII, A.L. Eenologia e exigências climáticas do feijoeiro. In: FANCELLI, A.L., ed. Feijão irrigado. Piracicaba, EEALQ, 1990. p.7-24.

EERRAZ, S. La mancha foliar angular. In: SCHWARTZ, H.E. \& GALVEZ, G.E., ed. Problemas de producción del frijol; enfermedades, insectos, limitaciones edáficas y 
climáticas de Phaseolus vulgaris. Cali, Centro Internacional de Agricultura Tropical, 1980. p.55-64.

GAUNT, R.E. Physiological basis of yield loss. In: PROCEEDINGS OF THE STAKMAN COMMEMORATIVE SYMPOSIUM ON CROP LOSS ASSESSMENT, 7. St. Paul, University of Minnesota, 1981. p.98-111. (Miscellaneous Publication, 7).

GODOY, C.V.; IAMAUTI, M.T.; DALLA PRIA, M.; CARNEIRO, S.M.T.P.G.; AMORIM, L.; BERGAMIN FILHO, A. Escalas diagramáticas para avaliação das principais doenças do feijoeiro. In: CONGRESSO BRASILEIRO DE FITOPATOLOGIA, 16. Ilhéus, 1995. Resumos. Fitopatologia Brasileira, Brasília, 20 (supl.): 338, 1995.

HAU, B.; KRANZ, J.; DENGEL, H.J. \& HAMELINK, J. On the development of loss assessment in the tropics. In: TENG, P.S. \& KRUPA S.V., ed. Crop loss assessment. St. Paul, University of Minnesota, 1980. p.254-61.

HAVERKORT, A.J. \& BICAMUMPAKA, M. Correlation between intercepted radiation and yield on potato crops infested by Phytophthora infestans in central Africa. Netherlands Journal of Plant Pathology, Wageningen, 92 : $239-47,1986$.

HORSFALL, J.G. \& BARRATT, R.W. An improved grading system for measuring plant diseases (abstr.). Phytopathology, St. Paul, 35: 655, 1945. 
IAMAUTI, M.T. Avaliação de danos causados por Uromyces appendiculatus no feijoeiro. Piracicaba, 1995. 81p. (Doutorado - Escola Superior de Agricultura "Luiz de Queiroz"/USP)

ISSA, E.; SINIGAGLIA, C.; OLIVEIRA, D.A. Controle químico da mancha angular da folha, Isariopsis griseola Sacc., do feijoeiro, Phaseolus vulgaris L.. o Biológico, São Paulo, 48 (12): 299-303, 1982.

JAMES, W.C. Assessment of plant diseases and losses. Annual Review of Phytopathology, Palo Alto, 12: 27-48, 1974 .

JAMES, W.C.; SHIH, C.S.; HODGSON, W.A.; CALLBECK, L.C. The quantitative relationship between late blight of potato and loss in tuber yield. Phytopathology, st. Paul, 62: $92-6,1972$.

JAMES, W.C. \& TENG, P.S. The quantification of production constraints associated with plant diseases. Applied Biology, London, 4: 201-67, 1979.

JOHNSON, K.B. Defoliation, disease and growth: a reply. phytopathology, St. Paul, 77: 1495-97, 1987.

KIMATI, H. Doenças do feijoeiro. In: GALLI, F., ed. Manual de fitopatologia. São Paulo, Ceres, 1980. v. 2, p. 297-318. 
LANTER, J.M. Epidemiology of angular leaf spot in monocultures and in bean - maize intercrops. Berkeley, 1990. 128p. (Doctor. - University of California).

LARGE, E.C. Measuring plant diseases. Annual Review of Phytopathology, Palo Alto, 4: 9-28, 1966.

LIM, L.G. \& GAUNT, R.E. The effect of powdery mildew (Erisyphe graminis f. sp. hordei) and leaf rust (Puccinia hordei) on spring barley in New Zealand. I Epidemic development, green leaf area and yield. Plant Pathology, London, 35: 44-53, 1986.

LLANOS, M. Patogenicidad del Isariopsis griseola Sacc. en frijol (Phaseolus vulgaris L.). Acta Agronomica, Palmira, 7(2): 165-90, 1957.

LOPES, D.B.; BERGER, R.D.; BERGAMIN EILHO, A. Absorção da área foliar sadia (HAA): uma nova abordagem para a quantificação de dano e para o manejo integrado de doença. Summa Phytopathologica, Jaguariúna $20(3-4)$ : 14351, 1994.

MADDEN, L.V. Measuring and modeling crop losses at the field level. Phytopathology, St. Paul, 73(11): 1591-96, 1983.

MADEIRA, A.C.; CLARK, J.A.; ROSSALL, S. Growth, light interception and disease in field bean (Vicia faba): the effect of late infection by Ascochyta fabae. Annals of Applied Biology, London, 112: 585-95, 1988. 
MAIN, C.E. Crop destruction - The raison d'être of plant pathology. In: HORSFALL, J.G. \& COWLING, E.B., ed. Plant disease; an advanced treatise. New York, Academic Press, 1977. v.1, p.55-75.

MCEWEN, J. Effects of defoliating different zones on the plant in field beans (Vicia faba L.). Journal Agriculture Science, Cambridge, 78:487-90. 1972.

MENEZES, J.R. Manejo integrado de doenças do feijoeiro irrigado. In: SEMINÁRIO SOBRE PRAGAS, DOENÇAS E PLANTAS DANINHAS DO FEIJOEIRO, 5. Piracicaba, 1994. Anais. Piracicaba, FEALQ, 1994. p.112-22.

MIGLIORANZA, E. Modelo matemático-fisiológico para simular - crescimento e a produtividade da cultura do feijão (Phaseolus vulgaris L.). Viçosa, 1992. $184 \mathrm{p}$. (Doutorado - Universidade Eederal de Viçosa).

MILES, L.E. Some diseases of economic plants in Porto Rico. Phytopathology, St. Paul, 7: 345-51, 1917.

MORA-BRENES, B. Estimativa de perdas no rendimento de feijoeiro-comum (Phaseolus vulgaris L.) causadas pela mancha angular (Isariopsis griseola Sacc.) Viçosa, 1983. 60p. (M. S. - Universidade Federal de Viçosa).

MORA BRENES, B.; CHAVES, G.M.; ZAMBOLIM, L. Estimativas de perdas no rendimento de feijoeiro-comum (Phaseolus vulgaris L.) causadas pela mancha-angular (Isariopsis 
griseola Sacc.). In: CONGRESSO BRASILEIRO DE FITOPATOLOGIA, 16. Belém, 1983. (Resumo) Fitopatologia Brasileira, Brasilia, 8 (3): 599, 1983.

NUNES, W.M.C. Avaliação de danos causados pela antracnose (Colletotrichum Iindemuthianum (Sacc. \& Magn.) Scribner) do feijoeiro (Phaseolus vulgaris L.). Piracicaba, 1994. 72p. (Mestrado - Escola Superior de Agricultura "Luiz de Queiroz"/USP) .

PORTES, T.A. Ecofisiologia. In: ZIMMERMANN, M.J. DE O.; ROCHA, M.; YAMADA, T., ed. Cultura do feijoeiro; fatores que afetam a produtividade. Piracicaba, Associação Brasileira para Pesquisa da Potassa e do Eosfato, 1988. p. p7-123.

RODRIGUES, C.H.; ZAMBOLIM, L.; MARTINS, M.C.P. Eficiência de fungicidas no controle da mancha angular (Isariopsis griseola) do feijoeiro (Phaseolus vulgaris). Fitopatologia Brasileira, Brasilia, 12 (1): 40-5, 1987.

ROTEM, J.; BASHI, E. \& KRANZ, J. Studies of crop loss in potato late blight caused by Phytophthora infestans. Plant Pathology, London, 32: 117-22, 1983.

SAETTLER, A.W. Angular leaf spot. In: HALL, R., ed. Compendium of bean diseases. Guelph, Ontario, APS Press, 1991. p.15-6.

SARTORATO, A. Resistência vertical e horizontal do feijoeiro comum (Phaseolus vulgaris L.) a Isariopsis 
griseola Sacc. Piracicaba, 1989. 13p. (DoutoradoEscola Superior de Agricultura "Luiz de Queiroz"/USP)

SARTORATO, A. \& RAVA, C.A. Influência da cultivar e do número de inoculações na severidade da mancha angular (Isariopsis griseola) e nas perdas na produção do feijoeiro comum (Phaseolus vulgaris). Fitopatologia Brasileira, Brasilia, 17: 247-51, 1992.

SARTORATO, A. \& RAVA, C.A. Mancha angular. In: SARTORATO, A. \& RAVA, C.A., ed. Principais doenças do feijoeiro comum e seu controle. Brasília: EMBRAPA/CNPAF, 1994. p.41-68. (EMBRAPA/CNPAE. Documentos, 50)

SCHWARTZ, H.F. Anthracnose. In: HALL, R., ed. Compendium of bean diseases. Guelph, Ontario, APS Press, 1991. p.16-7.

SCHWARTZ, H.F.; CORREA, F.J.; PENEDA-D., P.A.; OTOYA, M.M.; KATHERMAN, M.J. Dry bean yield losses caused by Ascochyta, angular and white leaf spots in Colombia. Plant Disease, St. Paul, 65: 494-6, 1981.

van OIJEN, M. Photosynthesis is not impaired in healthy tissue of blighted potato plants. Netherlands Journal of Plant Pathology, Wageningen, 96: 55-63, 1990.

VANDERPLANK, J.E. Plant diseases: epidemics and control. New York, Academic Press, 1963. 344p. 
WAGGONER, P.E. \& BERGER, R.D. Defoliation, disease and growth. Phytopathology, st. Paul, 77(3): 393-8, 1987.

YANG, X.B.; TSCHANZ, A.T.; DOWLER, W.M.; WANG, T.C. Development of yield loss models in relation to reductions of components of soybean infected with Phakopsora pachyrhizi. Phytopathology, St. Paul, $81(11): 1420-6,1991$.

ZADOKS, J.C. On the conceptual basis of crop loss assessment: the threshold theory. Annual Review of Phytopathology, Palo Alto, 23: 455-73, 1985. 
APÊNDICES 


\begin{tabular}{|c|c|c|c|c|c|}
\hline Carioca & Dia/Mês & $\begin{array}{l}\text { R. Global } \\
\mathrm{cal} / \mathrm{cm}^{2} \star \text { dia }\end{array}$ & Rosinha & Dia/Mês & $\begin{array}{l}\text { R. Global } \\
\mathrm{cal} / \mathrm{cm}^{2} \star \text { dia }\end{array}$ \\
\hline 1993 & $\begin{array}{l}29 / 3 \\
30 / 3 \\
31 / 3 \\
1 / 4 \\
2 / 4 \\
3 / 4 \\
4 / 4 \\
5 / 4 \\
6 / 4 \\
7 / 4 \\
8 / 4 \\
9 / 4 \\
10 / 4 \\
11 / 4 \\
12 / 4 \\
13 / 4 \\
14 / 4 \\
15 / 4 \\
16 / 4 \\
17 / 4 \\
18 / 4 \\
19 / 4 \\
20 / 4 \\
21 / 4 \\
22 / 4 \\
23 / 4 \\
24 / 4 \\
25 / 4 \\
26 / 4 \\
27 / 4 \\
28 / 4 \\
29 / 4 \\
30 / 4 \\
1 / 5 \\
2 / 5 \\
3 / 5 \\
4 / 5 \\
5 / 5 \\
6 / 5 \\
7 / 5 \\
8 / 5 \\
9 / 5 \\
10 / 5 \\
11 / 5 \\
\end{array}$ & $\begin{array}{l}159 \\
423 \\
375 \\
129 \\
141 \\
275 \\
399 \\
405 \\
320 \\
381 \\
195 \\
383 \\
413 \\
389 \\
378 \\
351 \\
363 \\
401 \\
308 \\
419 \\
399 \\
402 \\
356 \\
339 \\
348 \\
275 \\
371 \\
374 \\
351 \\
389 \\
366 \\
378 \\
371 \\
336 \\
306 \\
266 \\
351 \\
279 \\
180 \\
366 \\
371 \\
360 \\
363 \\
317 \\
\end{array}$ & 1994 & $\begin{array}{l}4 / 5 \\
5 / 5 \\
6 / 5 \\
7 / 5 \\
8 / 5 \\
9 / 5 \\
10 / 5 \\
11 / 5 \\
12 / 5 \\
13 / 5 \\
14 / 5 \\
15 / 5 \\
16 / 5 \\
17 / 5 \\
18 / 5 \\
19 / 5 \\
20 / 5 \\
21 / 5 \\
22 / 5 \\
23 / 5 \\
24 / 5 \\
25 / 5 \\
26 / 5 \\
27 / 5 \\
28 / 5 \\
29 / 5 \\
30 / 5 \\
31 / 5 \\
1 / 6 \\
2 / 6 \\
3 / 6 \\
4 / 6 \\
5 / 6 \\
6 / 6 \\
7 / 6 \\
8 / 6 \\
9 / 6 \\
10 / 6 \\
11 / 6 \\
12 / 6 \\
13 / 6 \\
14 / 6 \\
15 / 6 \\
16 / 6 \\
\end{array}$ & $\begin{array}{c}34 \\
360 \\
354 \\
345 \\
303 \\
239 \\
302 \\
284 \\
158 \\
83 \\
113 \\
236 \\
308 \\
342 \\
348 \\
341 \\
122 \\
276 \\
267 \\
207 \\
140 \\
305 \\
162 \\
63 \\
290 \\
252 \\
330 \\
321 \\
156 \\
287 \\
306 \\
126 \\
315 \\
297 \\
285 \\
95 \\
269 \\
305 \\
303 \\
335 \\
326 \\
284 \\
305 \\
249 \\
\end{array}$ \\
\hline
\end{tabular}

Apêndice 01. Dados de radiação global $\left(\mathrm{cal} / \mathrm{cm}^{2} \star d i a\right)$ para os períodos de avaliação dos ensaios. Datas em negrito correspondem às datas de avaliação. 

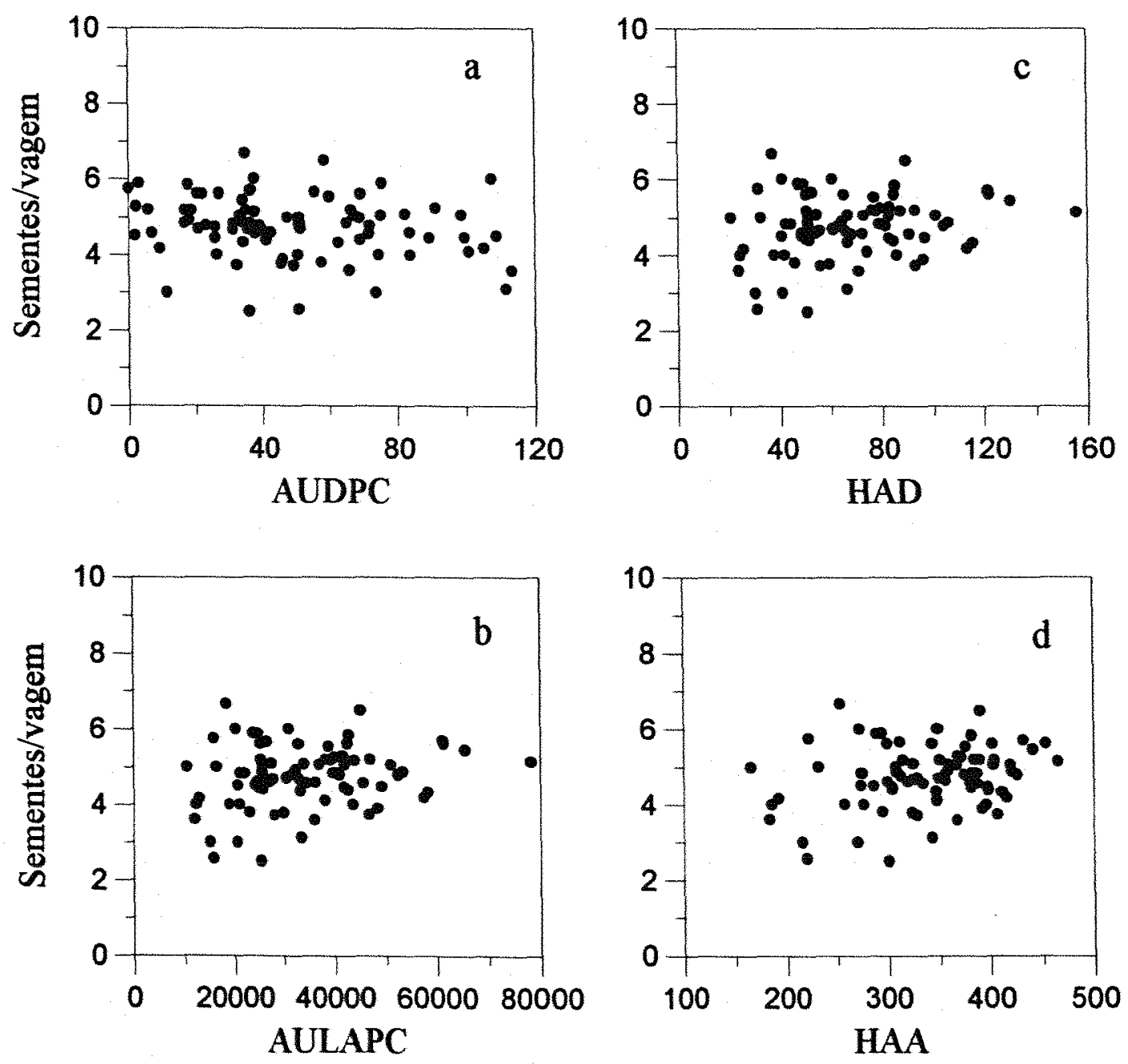

Apêndice 02. Relação entre as variáveis AUDPC (a), AULAPC (b), $\operatorname{HAD}$ (c) e HAA (d), e número de sementes por vagem para o cultivar Carioca. 

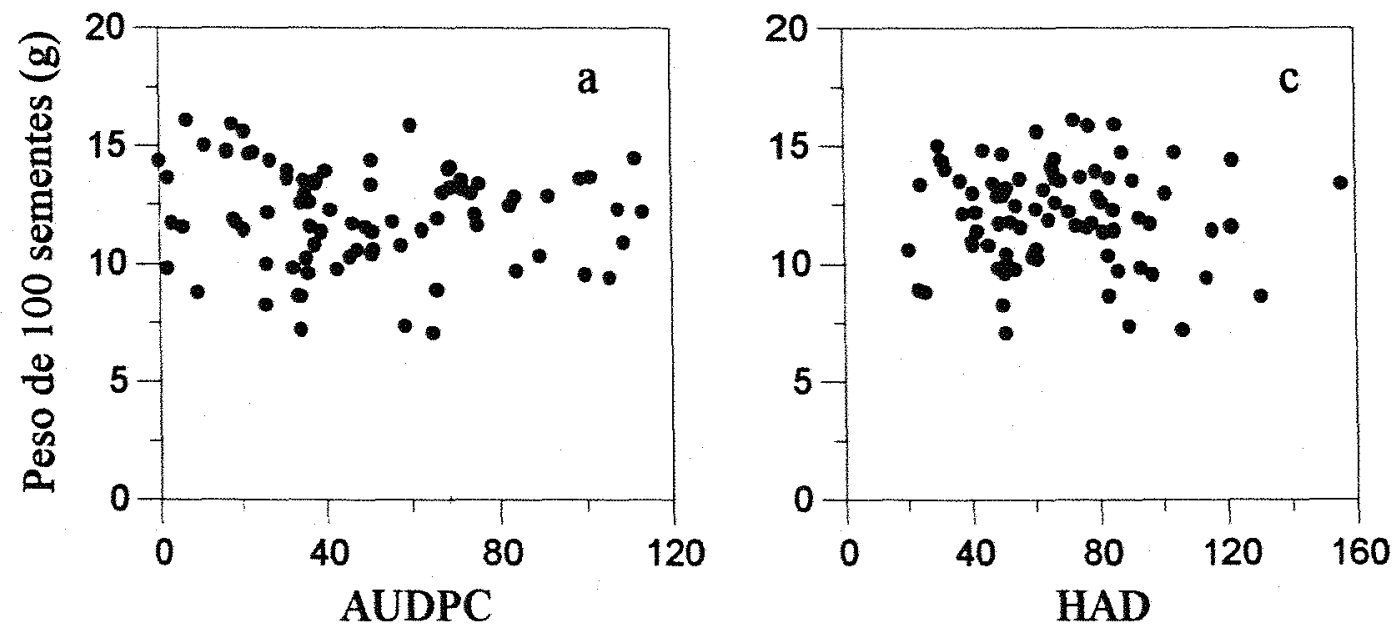

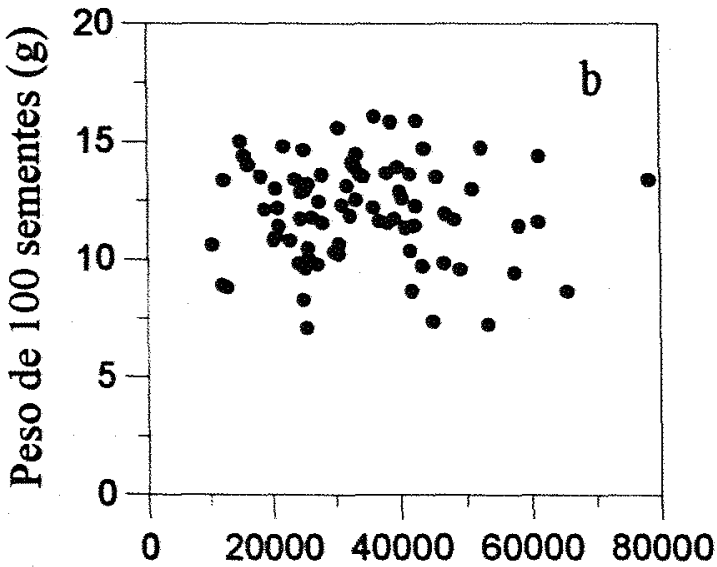

AULAPC

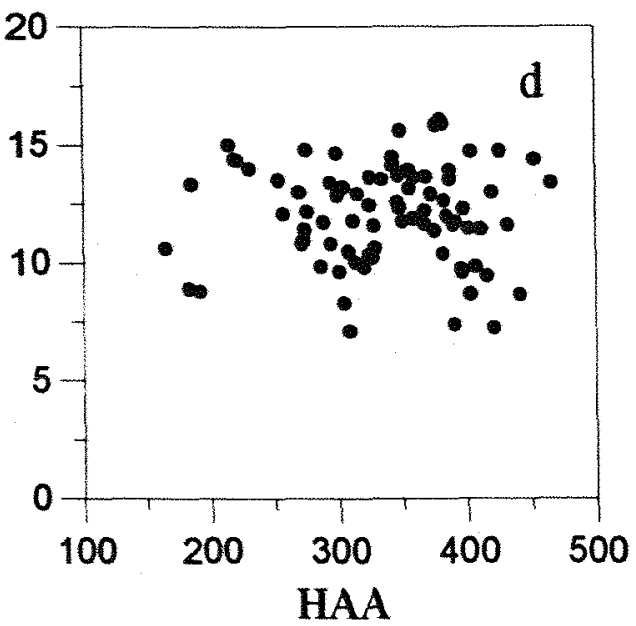

Apêndice 03. Relação entre as variáveis AUDPC (a), AULAPC (b), HAD (c) e HAA (d), e peso de 100 sementes para o cultivar Carioca. 


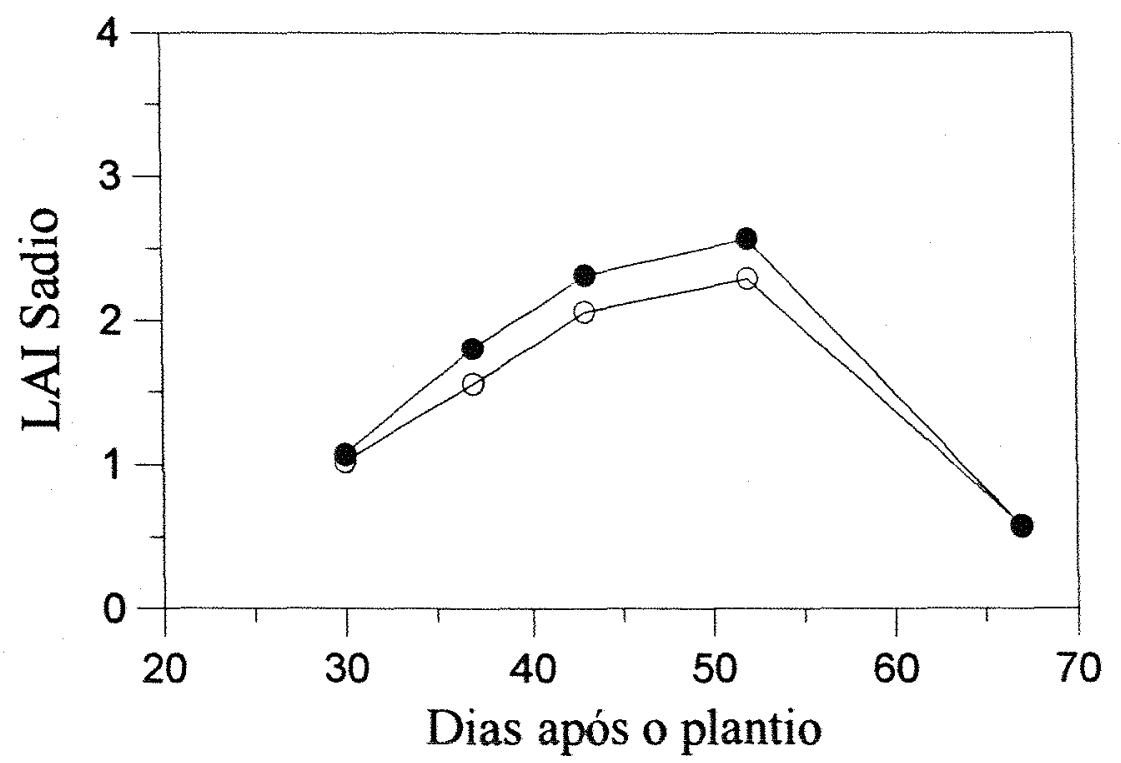

Apêndice 04. Curvas de progresso do indice de área foliar sadia para plantas sadias lo - média de 20 plantas) e doentes (* - média de 20 plantas) (cultivar Carioca). 

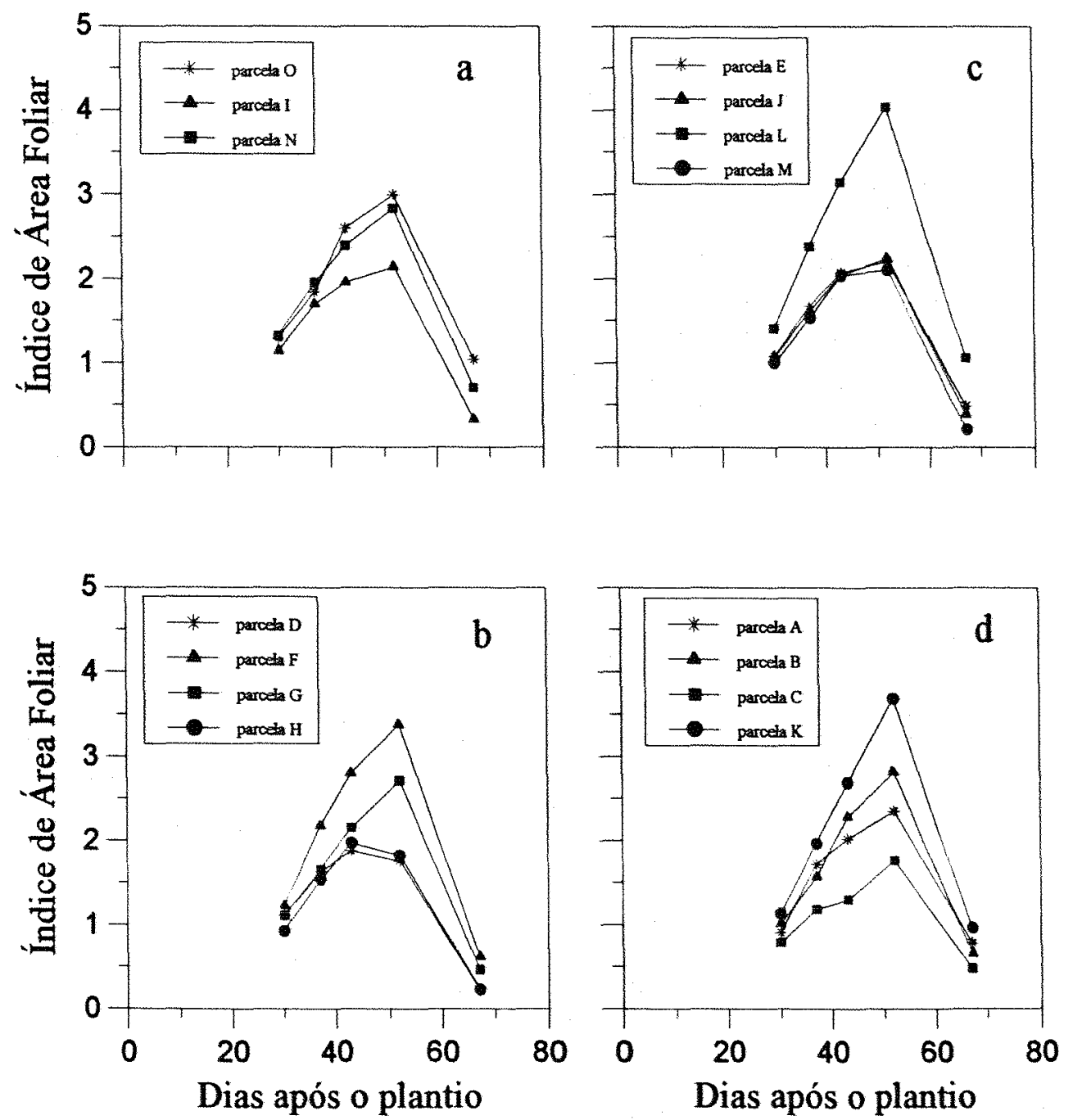

Apêndice 05. Curvas de progresso do indice de área foliar nas parcelas do cultivar Carioca com diferentes concentrações de inóculo. Cada curva representa a média das seis plantas de cada parcela. As concentrações do inóculo inicial crescem no sentido $a, c, b$ e $d$. 


\begin{tabular}{cc|cc}
\hline Parcela & $\begin{array}{c}\text { Produção } \\
\text { (gramas/planta) }\end{array}$ & Parcela & $\begin{array}{c}\text { Produção } \\
\text { (gramas/planta) }\end{array}$ \\
\hline A & 8.52 & I & 5.8 \\
B & 6.55 & J & 7.26 \\
C & 4.13 & K & 6.67 \\
D & 5.91 & L & 13.58 \\
E & 5.96 & M & 6.93 \\
F & 9.75 & N & 8.48 \\
G & 5.08 & O & 9.83 \\
H & 4.6 & & \\
\hline
\end{tabular}

Apêndice 06. Produções médias das seis plantas marcadas em cada parcela do ensaio com o cultivar Carioca. 

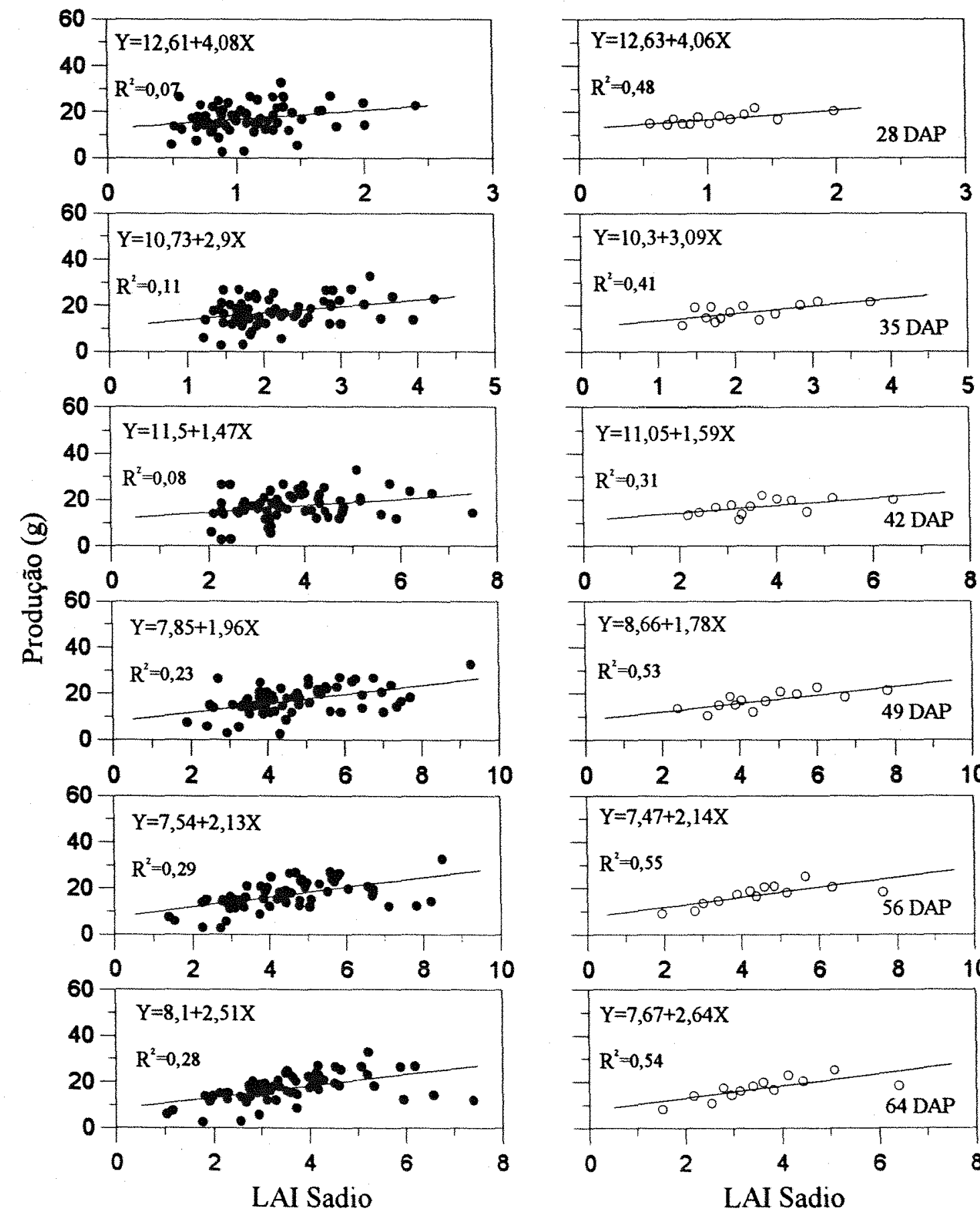

$$
\begin{aligned}
& 5
\end{aligned}
$$

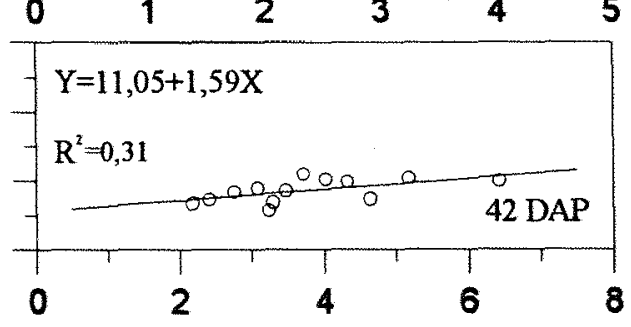$$
\begin{array}{|l}
\mathrm{Y}=8,66+1,78 \mathrm{X} \\
\mathrm{R}^{2}=0,53 \\
\hline \\
\hline
\end{array}
$$
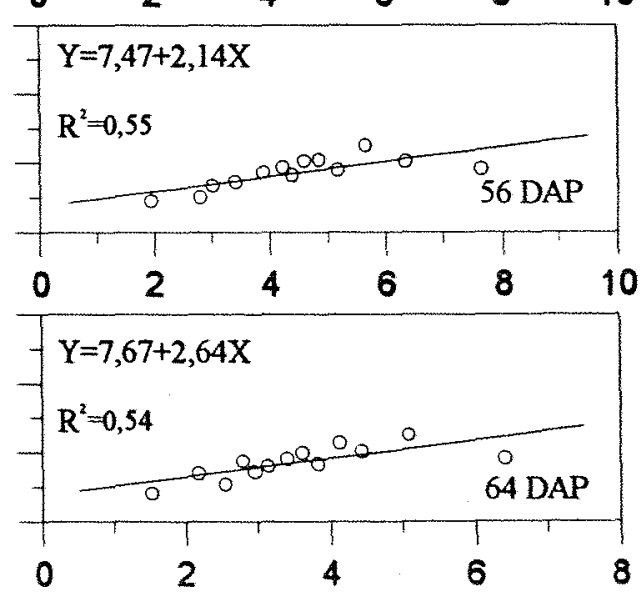

LAI Sadio

Apêndice 07. Relação entre índice de área foliar sadia e produção ( $g$ ) para as plantas sadias do cultivar Rosinha, nas seis datas de avaliação (- - todas plantas sadias, o - média de cinco plantas). 

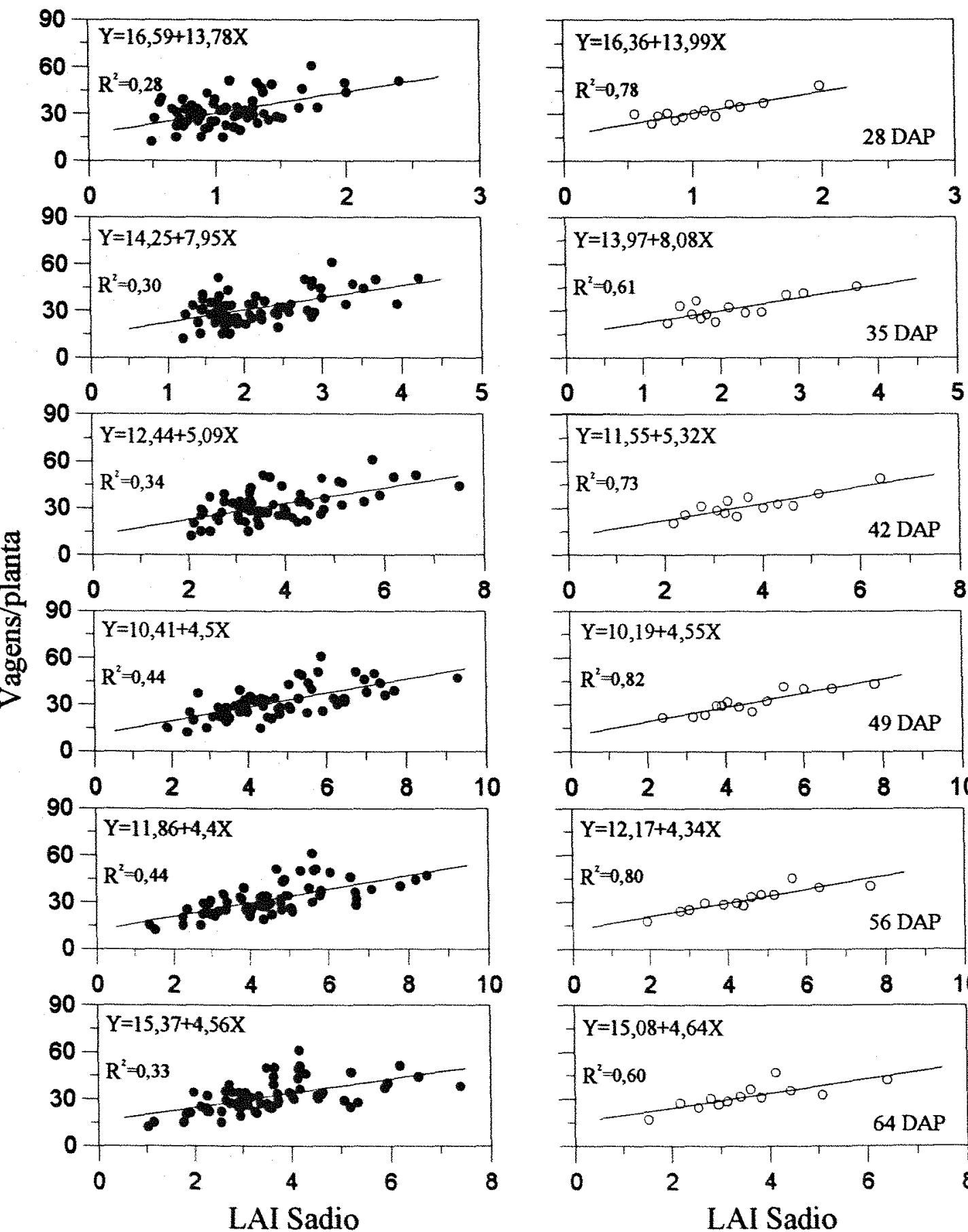

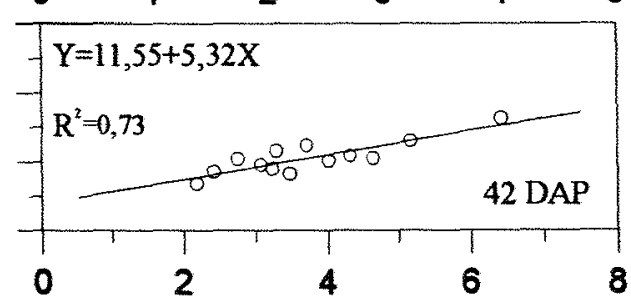
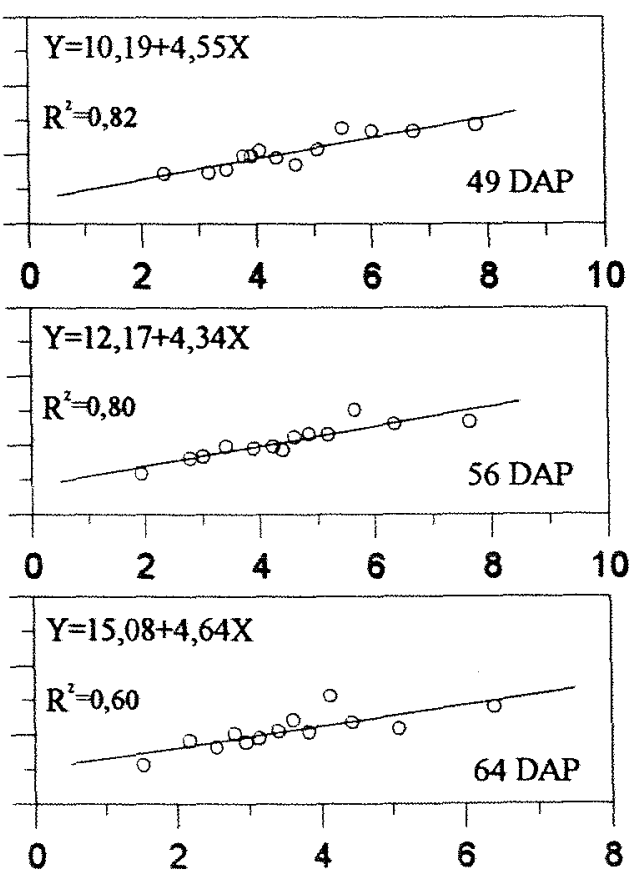

Apêndice 08. Relação entre indice de área foliar sadia e número de vagens por planta para as plantas sadias do cultivar Rosinha, nas seis datas de avaliação (• - todas plantas sadias, 0 média de cinco plantas). 